\title{
The pattern of glaciation on the Avalon Peninsula of Newfoundland
}

\section{L'histoire de la glaciation de la presqu'île d'Avalon, à Terre-Neuve. \\ Das Schema der Vereisung auf der Avalon-Halbinsel in Neufundland.}

\author{
Norm R. Catto
}

Volume 52, numéro 1, 1998

URI : https://id.erudit.org/iderudit/004778ar

DOI : https://doi.org/10.7202/004778ar

Aller au sommaire du numéro

Éditeur(s)

Les Presses de l'Université de Montréal

ISSN

0705-7199 (imprimé)

1492-143X (numérique)

Découvrir la revue

Citer cet article

Catto, N. R. (1998). The pattern of glaciation on the Avalon Peninsula of Newfoundland. Géographie physique et Quaternaire, 52(1), 23-45. https://doi.org/10.7202/004778ar
Résumé de l'article

L'histoire de la glaciation de la presqu'île d'Avalon a été établie à partir de l'étude des caractéristiques géomorphologiques, des stries et de la provenance des blocs erratiques. On distingue trois phases dans un continuum de glaciation. Pendant la première phase, il y a eu accumulation et dispersion de la glace à partir de plusieurs centres. Au cours de la deuxième période, qui correspond au Wisconsinien supérieur, les glaciers ont atteint un maximum en étendue et en épaisseur. Le niveau marin abaissé a permis la formation d'un centre glaciaire à l'emplacement de la baie St. Mary. Le glacier en provenance de la partie continentale de Terre-Neuve a fusionné avec celui de la presqu'île d'Avalon dans la baie de Plaisance, sur l'isthme et dans la baie de la Trinité. La troisième phase, caractérisée par la remontée du niveau marin et déclenchée par le recul de l'Inlandsis laurentidien au Labrador, a déséquilibré la calotte glaciaire de St. Mary. La déglaciation finale de la presqu'île d'Avalon a commencé avant $10100 \pm 250 \mathrm{BP}$. L'évolution des calottes glaciaires de la presqu'île d'Avalon a été déterminée par des événements régionaux et hémisphériques et par la réponse des glaciers laurentidiens.
Tous droits réservés @ Les Presses de l'Université de Montréal,1998

Ce document est protégé par la loi sur le droit d'auteur. L’utilisation des services d'Érudit (y compris la reproduction) est assujettie à sa politique d'utilisation que vous pouvez consulter en ligne.

https://apropos.erudit.org/fr/usagers/politique-dutilisation/ 


\section{THE PATTERN OF GLACIATION ON THE AVALON PENINSULA OF NEWFOUNDLAND}

Norm R. CATTO, Department of Geography, Memorial University of Newfoundland, St. John's, Newfoundland, A1B 3X9, ncatto@morgan.ucs.mun.ca.

Manuscrit reçu le 21 mars 1996 ; manuscrit révisé et accepté le 22 août 1997

ABSTRACT The pattern of glaciation on the Avalon Peninsula has been established through study of geomorphic features, striations, and erratic provenance. Three phases in a continuum of glaciation are recognized. The initial phase involved the expansion of ice from several centres. Ice thickness and extent reached a maximum during the subsequent Phase 2 event, correlated with the Late Wisconsinan. Lowered sea level permitted the development of the St. Mary's Bay ice centre. Ice from the Newfoundland mainland coalesced with Avalon Peninsula ice in Placentia Bay, on the Isthmus, and in Trinity Bay. Rising sea level, triggered by the retreat of Laurentide ice in Labrador, resulted in destabilization of the St. Mary's Bay ice cap, marking Phase 3. Final deglaciation of the Avalon Peninsula began before 10,100 \pm 250 BP. The Avalon Peninsula ice caps were controlled by regional and hemispheric events, and by the response of the Laurentide glaciers.
RÉSUMÉ L'histoire de la glaciation de la presqu'île d'Avalon, à Terre-Neuve. L'histoire de la glaciation de la presqu'île d'Avalon a été établie à partir de l'étude des caractéristiques géomorphologiques, des stries et de la provenance des blocs erratiques. On distingue trois phases dans un continuum de glaciation. Pendant la première phase, il y a eu accumulation et dispersion de la glace à partir de plusieurs centres. Au cours de la deuxième période, qui correspond au Wisconsinien supérieur, les glaciers ont atteint un maximum en étendue et en épaisseur. Le niveau marin abaissé a permis la formation d'un centre glaciaire à l'emplacement de la baie St. Mary. Le glacier en provenance de la partie continentale de Terre-Neuve a fusionné avec celui de la presqu'île d'Avalon dans la baie de Plaisance, sur l'isthme et dans la baie de la Trinité. La troisième phase, caractérisée par la remontée du niveau marin et déclenchée par le recul de l'Inlandsis laurentidien au Labrador, a déséquilibré la calotte glaciaire de St. Mary. La déglaciation finale de la presqu'île d'Avalon a commencé avant $10100 \pm 250$ BP. L'évolution des calottes glaciaires de la presqu'île d'Avalon a été déterminée par des événements régionaux et hémisphériques et par la réponse des glaciers laurentidiens.
ZUSAMMENFASSUNG Das Schema der Vereisung auf der Avalon-Halbinsel in Neufundland. Das Schema der Vereisung auf der Avalon-Halbinsel wurde mittels des Studiums der geomorphologischen Merkmale, der Schrammen und der Herkunft der erratischen Blöcke nachgezeichnet. In der Anfangsphase dehnte sich das Eis ausgehend von mehreren Zentren aus. Das Eis erreichte ein Maximum an Dicke und Ausdehnung in der folgenden 2. Phase, die dem späten Wisconsin entspricht. Der niedrigere Meeresspiegel ermöglichte die Entwicklung des Eiszentrums der St. Mary's -Bai. Das Eis vom Festland Neufundlands vereinigte sich mit dem Eis der Avalon-Halbinsel in der Placentia-Bai, auf dem Isthmus und in der Trinity-Bai. In Phase 3 führte ein ansteigender Meeresspiegel, ausgelöst durch den Rückzug des laurentischen Eises in Labrador, zur Destabilisierung der Eiskappe der St. Mary's-Bai. Die endgültige Enteisung der Avalon-Halbinsel begann vor $10100 \pm 250$ v.u.Z. 


\section{INTRODUCTION}

Investigation and assessment of ice-flow directions in regions marked by limited sedimentary deposition represents a complex but persistent problem in Quaternary studies. Although recognition of the occurrence of glaciation is generally a straightforward matter, more precise understanding of the patterns of glacial movement is required for geotechnical or resource management purposes. In addition, construction of glaciological or glacio-climatic models requires information concerning glacial extents, volumes, and accumulation areas. The more recent of these models attempt to incorporate data from localized glacial sources surrounding the North Atlantic, as well as that related to the Laurentide and Fennoscandian glaciers (e.g. Velichko et al., 1997).

Throughout Atlantic Canada, the hypothesis of multiple glacial ice caps independent of the Laurentide Ice Sheet complex has gained support through numerous investigations (e.g. Chalmers, 1895; Jenness, 1960; Prest, 1973; Grant, 1974, 1977, 1989; Brookes, 1982, 1989; Seaman et al. ,1991; Stea et al. ,1992; Stea, 1995). Assessment of the directions of ice movement necessary to support these hypotheses has necessitated careful examination of all glacigenic depositional and erosional features, with heavy reliance on geomorphic forms and the distribution of glacially transported erratics, and with the realization that these indicators may produce results that initially seem incompatible (cf. Schau, 1981).

The Avalon Peninsula is one region in Atlantic Canada that has been postulated to have supported one or more independent ice caps. Investigation of the Avalon Peninsula, therefore, serves as an illustration of the applicability of these techniques, as well as resulting in clarification of the patterns of glacial flow. This report discusses investigations undertaken on the Avalon Peninsula throughout the period 1989 -1996, associated with detailed mapping at 1:50,000 and larger scales (Catto, 1992a, 1992b, 1993, 1994a, 1994b; Taylor et al., 1994; Catto and St. Croix, in press; House and Catto, 1995; and additional unpublished data filed in the Government of Newfoundland and Labrador Quaternary Data Repository system ${ }^{1}$ ).

\section{REGIONAL SETTING}

The Avalon Peninsula (Fig. 1) represents the easternmost land mass of North America. The peninsula is connected to the main part of Newfoundland by the Isthmus of Avalon, with a minimum width of $4 \mathrm{~km}$ at its northern end. The peninsula and isthmus encompass approximately $10,000 \mathrm{~km}^{2}$, and no location is more than $30 \mathrm{~km}$ from the coast. The AvaIon Peninsula can be conveniently divided into four sub-peninsulas: Placentia, Carbonear, St. John's, and Trepassey (Fig. 1). Each of the sub-peninsulas trends northeast-south-

1. These data represent new information added between 1994 and 1996 to the database maintained by the Department of Mines and Energy, Government of Newfoundland and Labrador. west. Heights of land follow the axes of the sub-peninsulas, with maximum elevations in excess of $330 \mathrm{~m}$. Most of the area is below $150 \mathrm{~m}$ a.s.l.

The heights of land throughout the Avalon Peninsula follow the axes of the major sub-peninsulas, resulting in the development of drainage systems marked by short, steep gradient streams with small catchment areas. The bays between the sub-peninsulas vary in depth. The maximum depths in Conception Bay (in excess of $280 \mathrm{~m}$ ), Placentia Bay (in excess of $300 \mathrm{~m}$ ), and Trinity Bay (in excess of 580 m) follow the structural trends. In contrast, St. Mary's Bay is relatively shallow, with a maximum depth of $210 \mathrm{~m}$ and a modal depth of $120 \mathrm{~m}$ south of Great Colinet Island. Seaward access to the bay is further impaired by the shallow St. Mary's Bank, with a maximum depth of $65 \mathrm{~m}$, extending across the mouth of the bay from St. Shotts to Point Lance.

\section{PREVIOUS WORK}

After erratic boulders and glacial features on the Avalon Peninsula were recognized (Jukes, 1842, 1843; Kerr, 1870; Milne, 1874, 1876, 1877; Packard, 1876), debate centred upon the origin of the glacial features. Several authors, including Murray (1883), Flint (1940), Twenhofel and MacClintock (1940), and Tanner (1944), advanced the view that the Avalon Peninsula was glaciated by ice originating to the northwest, either from the main part of Newfoundland or from the Laurentide complex based in western Labrador. In contrast, Chamberlin (1895) suggested that the Avalon Peninsula had been covered by an independent, radially-flowing ice cap. The ice cap hypothesis was supported subsequently by Coleman (1926) and Summers (1949), based primarily on the absence of granitic erratics in the central part of the AvaIon Peninsula. Summers (1949), however, noted granitic clasts derived from local Avalon sources, and reported ultramafic erratics of unknown provenance.

The most comprehensive study of Quaternary events on the Avalon Peninsula was that undertaken by Henderson (1972). Based primarily on the analysis of striation patterns, but also incorporating roche moutonnée orientations and till fabric analysis, Henderson recognized that the Avalon Peninsula had supported independent ice caps throughout the Wisconsin. Ice from the mainland of Newfoundland overrode the Isthmus of Avalon from west to east, but was precluded from covering the remainder of the peninsula by local glaciers. Henderson suggested that the confluence zone crossed the Isthmus between Fair Haven and Collier Bay.

Henderson recognized three distinctive glacial source areas on the Avalon Peninsula. The majority of the area, including the Placentia and Trepassey sub-peninsulas and southern Trinity and Conception Bays, was glaciated by ice flowing radially from a source in St. Mary's Bay, in the vicinity of Great Colinet Island (Henderson, 1972). Individual areas, however, exhibited striations that were not strictly compatible with this regional picture. Striations suggesting flow towards the postulated St. Mary's Bay source were recorded along the eastern coast of the bay between Point LaHaye and Holyrood Pond. 
FIGURE 1. The Avalon Peninsula. La péninsule d'Avalon

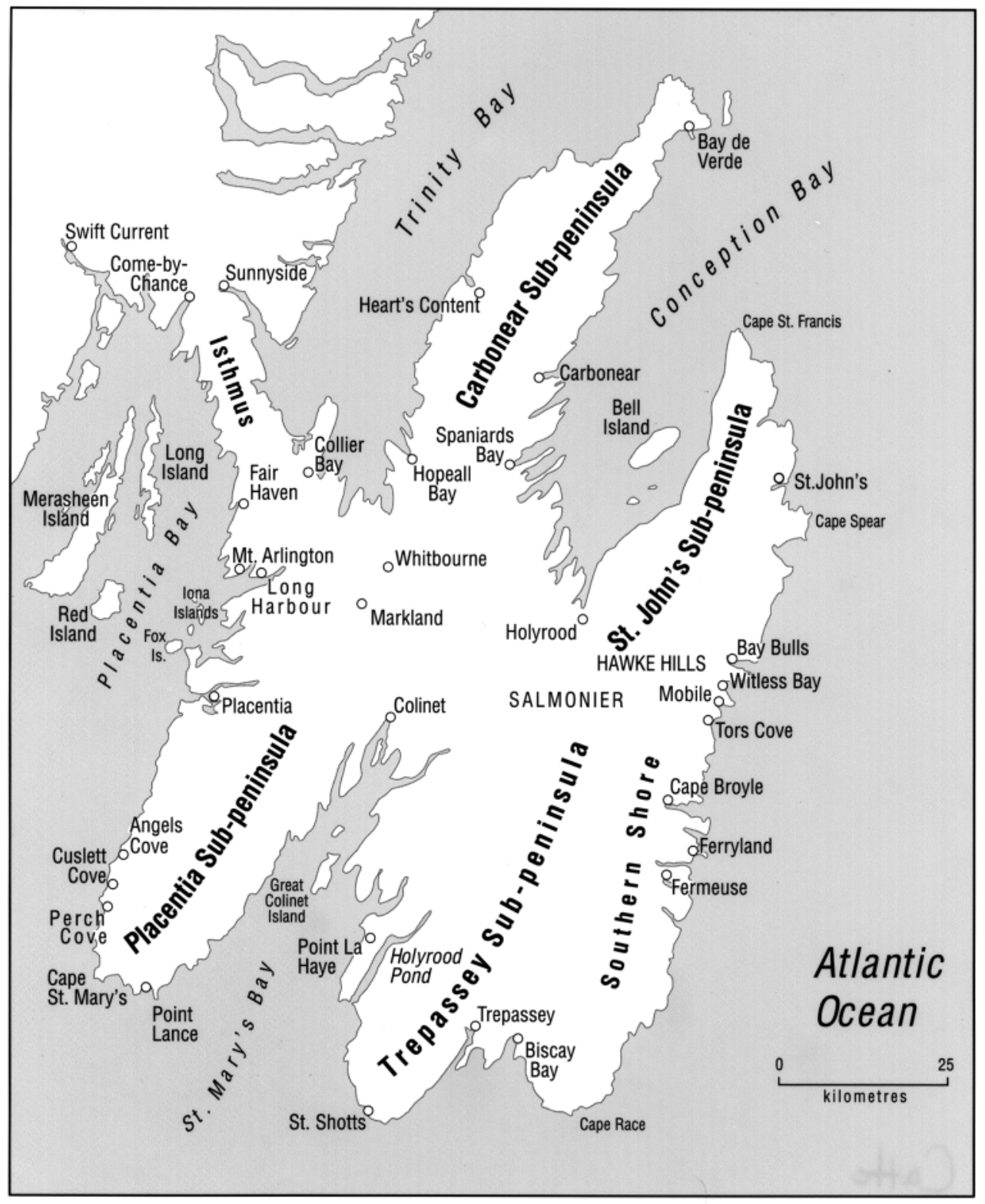

Ice divides were also recognized on the St. John's and Carbonear sub-peninsulas by Henderson (1972). Ice flowed seaward from a linear divide along the axis of the St. John's sub-peninsulas, reaching the coastlines of Conception Bay north of Holyrood and the Atlantic Ocean north of Bay Bulls. Slatt (1972) subsequently noted clast assemblages in glacial sediments in the Holyrood - Conception Bay South area that confirmed Henderson's interpretation. The Witless Bay Barrens area was considered by Henderson to represent the zone of coalescence between the St. John's sub-peninsula and St. Mary's Bay ice. On the Carbonear sub-peninsula, Henderson (1972) identified ice flow seaward from a divide aligned along the axis of the peninsula.

Rogerson and Tucker (1972) suggested that glacial retreat was marked by progressive recession from the coastal areas to the highest parts of the interior plateaux, particularly the Hawke Hills. This hypothesis is not entirely compatible with the St. Mary's Bay dome model proposed by Henderson (1972), although it does generally accord with his model for the St. John's sub-peninsula. The backwasting hypothesis for the Hawke Hills area was countered by Macpherson $(1982,1996)$. On the basis of palynological research, Macpherson argued that the uppermost summits were deglaciated before the lowermost areas, and suggested a down-wasting model for the northeastern Avalon Peninsula (Macpherson, 1996).

Vanderveer $(1975,1977)$ mapped most of the Avalon Peninsula and all of the isthmus. He identified additional striation sites and streamlined bedrock forms, the orientations of which were generally compatible with Henderson's (1972) model of ice flow. Near Fair Haven on the isthmus, striations 
mapped by Vanderveer (1977) suggested that this area was affected by local ice, rather than by the main Newfoundland ice sheet.

Regional studies of Newfoundland Quaternary geology published after Henderson's and Vanderveer's work have largely incorporated their conclusions (e.g. Grant, 1974, 1977, 1989; Rogerson, 1981, 1982; Brookes, 1982). These studies also demonstrated that the pattern of multiple ice caps and small ice sheets, marked by shifting glacial sources and flow directions, is common throughout Newfoundland. Thus, the style of glaciation of the Avalon Peninsula appears to mirror that of the Atlantic Provinces as a whole.

\section{BEDROCK STRUCTURE, LITHOLOGY, AND PROVENANCE INDICATORS}

In areas which generally lack thick successions of glacigenic sediments, the use of readily-identifiable clasts as indicators of provenance and ice-flow direction assumes considerable importance. The folded nature of the bedrock strata, however, has resulted in the exposure of identical or similar lithologic units along the axes of each of the sub-peninsulas, limiting their potential to produce distinctive clasts.

The Avalon Peninsula is dominated by Late Proterozoic clastic sedimentary, metasedimentary, and bimodal volcanic rocks (McCartney, 1967; King, 1988; Colman-Sadd et al., 1990; see Fig. 2). The units each contain a variety of lithologies, and consequently clasts derived from Late Proterozoic strata are not useful as provenance indicators. The single

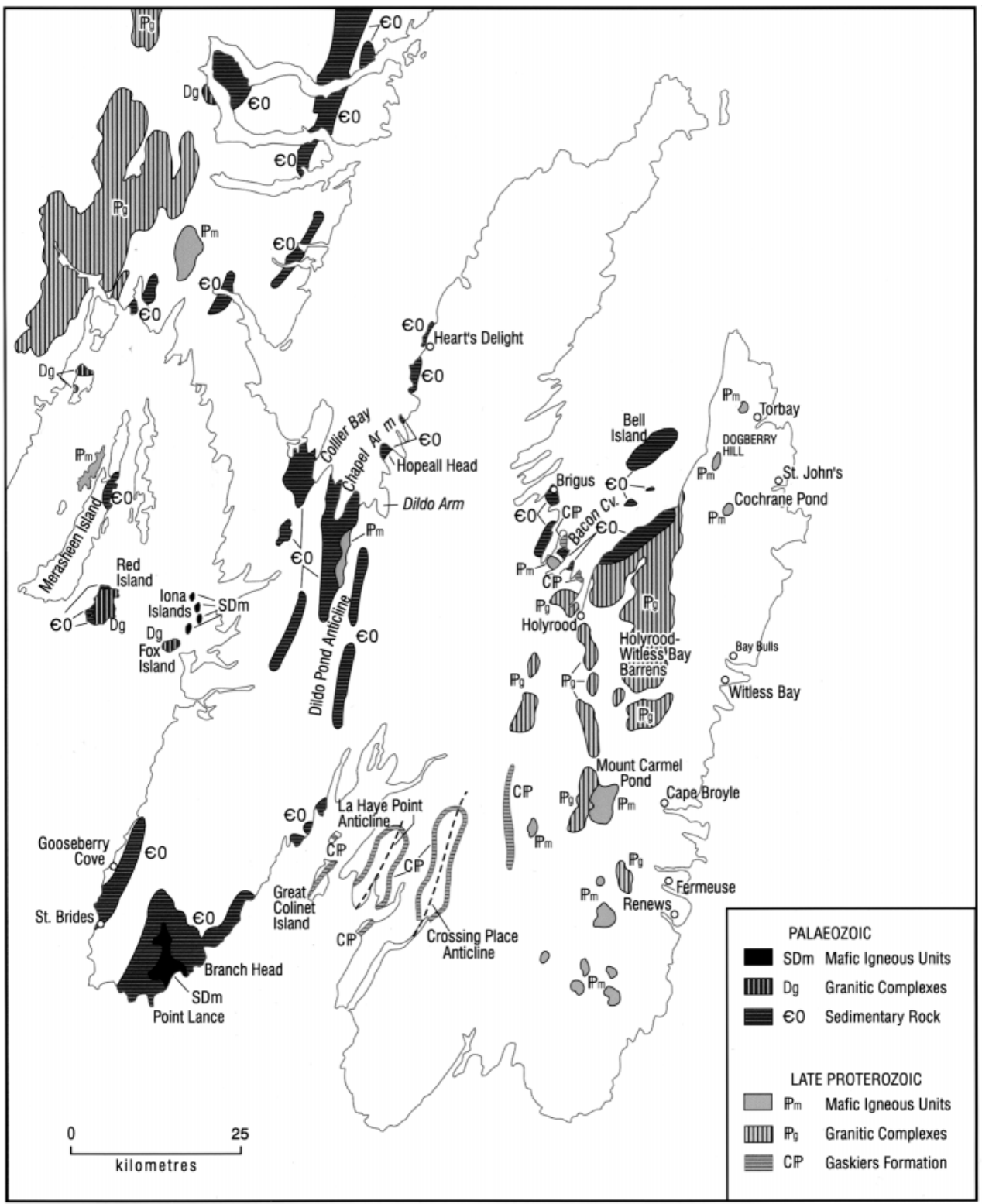

FIGURE 2. Distinctive Bedrock Units, Avalon Peninsula (after McCartney, 1967; King, 1988; Colman-Sadd et al. 1990).

Les unités du substratum de la péninsule d'Avalon (selon McCartney, 1967; King, 1988; Colman-Sadd et al. 1990). 
exceptions are clasts derived from the Gaskiers Formation, a Late Proterozoic diamictite (Eyles and Eyles, 1989). The Gaskiers Formation outcrops along the limbs of the LaHaye Point and Crossing Place Anticlines, and on Great Colinet and Little Colinet Islands (King, 1988), but does not outcrop along the western shore of St. Mary's Bay. Small outcrops along southernmost Conception Bay have been tentatively assigned to the Gaskiers Formation by King (1988).

Intrusive igneous rocks of Late Proterozoic to earliest Cambrian age have a limited distribution, and clasts of these are thus potentially useful as provenance indicators. Although a variety of rock types occur, two dominant suites are present. Mafic intrusions, predominantly gabbro, outcrop in the southeastern and central Trepassey sub-peninsula on the Carbonear sub-peninsula, and west of Whitbourne. Granitic intrusions, which locally include mafic units, outcrop throughout the Holyrood - Witless Bay Barrens area; west of Cape Broyle, Renews, and Fermeuse; and south of Harbour Main. Isolated serpentinized veins intrusions are present in the Witless Bay Barrens northeast to Cochrane Pond (Batterson, 1988).

The presence of mafic bodies within the granitic complexes implies that mafic clasts may have originated from either of the igneous suites. As the Late Proterozoic intrusions are absent from the Placentia and Carbonear sub-peninsulas, mafic erratics in these areas could serve as provenance indicators. The absence of granite from the Placentia, Carbonear, and western Trepassey sub-peninsulas also suggests that granitic clasts are potentially useful as provenance indicators.

Palaeozoic sedimentary units outcrop along the shoreline of Conception Bay, southern and southeastern Trinity Bay, southeastern Placentia Bay, and southwestern and western St. Mary's Bay. These units, with limited areal distributions and distinctive lithologies, are useful sources of diagnostic erratics. Palaeozoic sedimentary units also are present offshore of the Southern Shore, Trepassey, St. Mary's Bay, and Conception Bay shorelines. Palaeozoic granitic units are not present on the Avalon Peninsula, but are exposed on Red Island and Fox Island in Placentia Bay. Palaeozoic mafic intrusive suites are present on the lona Islands, in Placentia Bay, and in the Point Lance area.

Thus, the bedrock units which have the potential to supply distinctive erratics are the Gaskiers diamictite, the Late Proterozoic - Cambrian granitic units, and the Palaeozoic sedimentary and granitic units. Clasts derived from mafic units are potentially also of local importance, but must be interpreted with caution.

Use of erratics to indicate ice-flow direction is complicated by the potential for re-transport. Clasts eroded by an initial glacial event may be transported by one or more subsequent glaciations, producing erratic clast distributions at variance with the orientation of other ice-flow indicators, such as striations (e.g. Schau, 1981; Broster et al., 1997). Clasts derived from pre-glacial weathering may also be incorporated into glacial deposits, complicating analysis of glacial transport processes and directions (e.g. Astakhov, 1997; Cogley et al.,1997).

In this study, erratics are considered as evidence of glacial transport where they are present at locations topographically above their provenance areas, in situations where the clasts cannot be moved against gravity by other processes. This practice follows that common in western Canada, where clasts of Canadian Shield origin indicate southwestward and westward upslope movement of continental glaciers (e.g. McConnell, 1885; Kulig, 1996; and many others), and has proven to be useful in other less well-studied regions (Astakhov, 1997). Although individual erratics may have undergone multiple episodes of transport, the presence of clasts which have been transported upslope indicates glacial redistribution (cf. Broster et al., 1997).

\section{INDICATORS OF ICE FLOW: DATA AND METHODS OF ANALYSIS}

Geomorphic and sedimentary features are used extensively to establish sources and directions of glacial flow. Individual indicators are not considered to be independently representative of glacial flow: assessment of flow directions required that the orientations of all available indicators be considered as local and regional assemblages. The primary indicators used are streamlined bedrock forms; striations and associated micro-erosional features; and crag-and-tail features.

In addition to striation orientations reported previously by Henderson (1972) and Vanderveer (1977), data were collected during the course of 1:50,000 and larger scale mapping throughout the Avalon Peninsula. Nineteen 1:50,000 map sheets, published by the Government of Newfoundland and Labrador, incorporate the Quaternary geology and ice flow indicator data (Catto, 1992a, 1993, 1994a; Taylor et al., 1994). Data within the St. John's 1:50,000 map area have been discussed by Catto and St. Croix (in press) and are documented in Taylor et al. (1994). Additional ice-flow indicator data, including that collected between 1994 and 1996, have been deposited in the publicly accessible Quaternary database maintained by the Government of Newfoundland and Labrador. More than 800 sites with primary ice-flow indicators identified throughout the region are used in this study, including more than 100 sites which show two or more ice flow directions.

The distribution of ice-flow indicators throughout the Avalon region, including both striations and streamlined bedrock landforms, is illustrated in Figure 3. For clarity, the map depicts a representative sample of the more than 800 iceflow indicators present throughout the region, and also includes ice-flow indicators identified on Merasheen, Long, and Red Islands in Placentia Bay during recent investigations (Catto, in preparation).

Many sites throughout the Avalon Peninsula and Isthmus display both striations and streamlined bedrock landforms, each of which are considered as valid indicators of the ice 


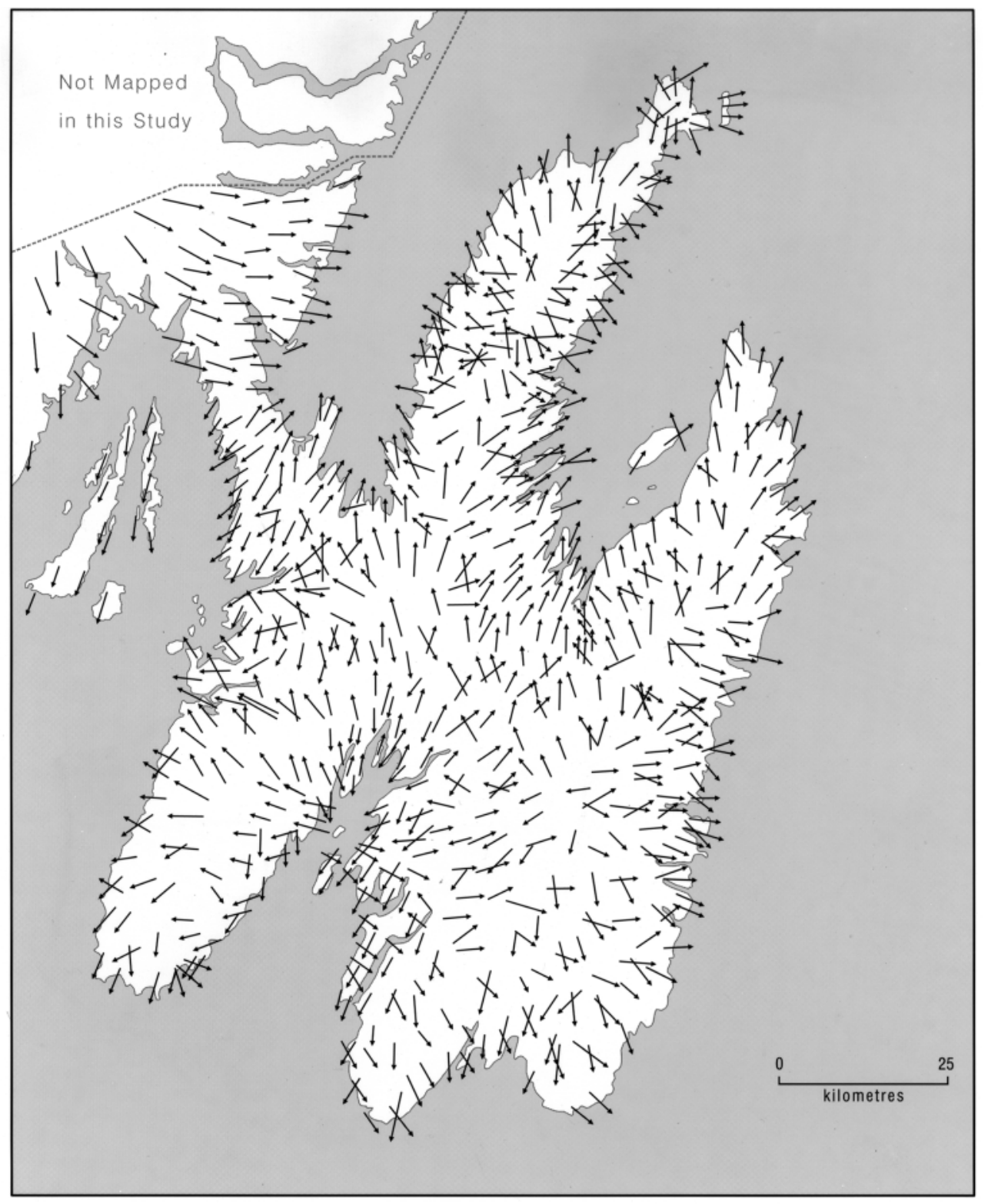

FIGURE 3. Ice Flow Indicators, Avalon Peninsula and adjacent Newfoundland. Ice flow directions illustrated (arrows) are based on striations and glacially eroded bedrock landforms. For clarity, the figure depicts a representative sample of all iceflow indicators measured, including both striations and streamlined landforms (Catto 1992a, 1993, 1994a; Catto and St. Croix in press; Catto and Thistle, 1993; Henderson, 1972; Taylor et al., 1994; Vanderveer, 1977). See text for further discussion.

Les indicateurs de l'écoulement glaciaire à la péninsule d'Avalon et aux environs. Les directions données (flèches) sont fondées sur les stries et les formes du substratum érodées par les glaces. Les données sont représentatives de tous les indicateurs mesurés, y compris les stries et les formes profilées (Catto 1992a, 1993, 1994a; Catto et St. Croix, sous presse; Catto et Thistle, 1993; Henderson, 1972; Taylor et al., 1994; Vanderveer, 1977). Voir le texte pour plus de détails.

flow directions at the instant of their formation. In many instances, the orientations of striations correspond to those of the streamlined features upon which they are developed. Assessment of the pattern of glaciation from the orientation of these features requires that they be considered simulatneously.

The formation of any erosional feature indicative of glacial flow requires the action of warm-based glacial ice. The ice flow directions indicated by the striations, roches moutonnées, and other features thus strictly indicate only those flow events where warm-based ice was involved. Cold-based glacial ice could have existed throughout the Avalon Peninsula on one or more occasions during the Quaternary, without producing glacial erosional features or modifying those formed by warm-based glaciers. By its nature, cold-based ice leaves limited geomorphological evidence, and its pres- ence (e.g. Grant, 1989) or absence (e.g. Brookes, 1989) elsewhere in Atlantic Canada has been established primarily by the spatial relationship of the cold-based zones to surrounding areas of terrain with glacial features. In areas where deglaciation prior to the Late Wisconsinan has been postulated, cosmogenic dating of postulated cold-based terrain (Gosse et al., 1995; Phillips, 1995) can establish the timing of the most recent deglaciation.

Both striations and roches moutonnées strictly represent warm-based glacial flow only during the period required for their formation, not the entire duration of glaciation. Extrapolation of glacial flow from striations is complicated by the limited time required for clasts in glacial transport to form individual striae, in contrast to the total duration of the glacial episode. In contrast, roches moutonnées and other streamlined features may represent longer intervals of glacial modi- 
fication, but also may have been subjected to different phases of development (cf. Sugden et al., 1992). Thus, analysis of glacial flow from striations and roches moutonnées involves some degree of uncertainty, and neither type of feature is necessarily more representative of the 'true' direction of glacial flow than is the other. Examples of typical erosional indicators of ice flow from the Avalon region are illustrated in Figure 4.

Streamlined bedrock forms, including roches moutonnées, whalebacks, and flyggbergs in excess of $100 \mathrm{~m}$ length (cf. Rudberg, 1992) are common throughout the Avalon Peninsula. Many of the larger features can be identified through analysis of aerial photographs, especially in the Barrens areas where sediment and vegetation cover are very limited or non-existent. Many smaller features, however, can only be recognized in the course of intensive field mapping. Oriented bedrock features of problematic origin are excluded from the analysis.

Many roches moutonnées showed evidence of streamlining in two distinct directions, suggesting separate phases of glacial flow. These features were marked by the superposition of small-scale erosional features on the stoss and crest of the larger form. As the susceptibility of any particular outcrop to streamlining depends upon the orientation of the rock structure and pre-existing morphology to the direction of ice flow (Lindström, 1989; Liverman, 1992; Rudberg, 1992; Sugden et al., 1992; Clark, 1993), use of streamlined bedrock features as ice flow indicators on the Avalon Peninsula requires consideration of the structural geology and the probable pre-glacial morphology.

Striations and other micro-erosional features are used as indicators of ice flow direction. Although many outcrops display two to six sets of crossing linear striations, multiple sets are assumed to represent distinctive events only where the range of flow directions for each set do not overlap. Sites at which the striations could not be assigned a definitive orientation are excluded from the analysis.

Crag-and-tail features are also used to assess ice flow direction, with the orientation of the diamicton tail considered to represent the modal ice flow direction at the period of deposition. The diamictons contain structures and clast fabrics indicative of deposition as lee-side cavity fills, following the criteria proposed by Dardis et al. (1984), Kaszycki (1987), and other researchers.

Identification of the diamicton 'tails' as lee-side deposits is important, as several bedrock obstructions are flanked by accumulations of diamicton along their stoss sides. These "diamicton ramps" (or "till ramps") resemble tails in form, especially on aerial photographs (e.g. Batterson and Liverman, 1995, their Plate 16). Identification of ramps depends on diamicton fabric and their relationship to other ice-flow indicators. Diamicton ramps, therefore, cannot be used as 'independent' ice-flow indicators.

Rogen moraines (Lundqvist, 1969), flutings, and drumlinoid ridges are present in several areas of the Avalon Peninsula. A variety of formative mechanisms, including deposition or moulding by active subglacial ice (Lundqvist, $1969,1989)$, deposition by combinations of subglacial meltout and basal thrusting (Shaw, 1979; Bouchard, 1989), erosion by subglacial meltwater (Shaw, 1983, 1994; Shaw et al. 1989), and deposition by subglacial meltwater (Fisher and Shaw, 1992) have been suggested. Although the alignment of the landforms is generally assumed to be related to ice flow direction, this assumption may be invalid if they are produced by subglacial meltwater moving along a topographic surface not aligned parallel to ice flow (Munro, 1994; Munro and Catto, in press). To exclude any possibility of uncertainty, the orientations of Rogen moraines are not used here as independent ice-flow indicators. Micro-erosional features attributed to flowing subglacial meltwater by some investigators (e.g. Dreimanis, 1993) are also excluded from the analysis.

\section{ICE CENTRES AND FLOW DIRECTIONS}

Analysis of the more than 800 ice flow indicators identified throughout the Avalon Peninsula (Catto, 1992a, 1993, 1994a; Taylor et al., 1994) has revealed a complex pattern of glaciation, marked by shifting ice centres and variable directions of flow. Several distinct ice centres are recognized (Fig. 5).

The distribution of erosional features throughout the AvaIon Peninsula and Isthmus (see Fig. 3) indicates that all parts of this region were subjected to warm-based glacial erosion during some parts of the Quaternary period. Terrain indicative of cold-based glacial activity has not been identified, and the relative durations of cold-based (if any) and warm-based glacial activity are impossible to assess at present.

The pattern of glaciation involved three phases which appear to form a continuum. Small ice caps formed throughout the initial phase of glaciation recorded on the Avalon Peninsula. The relative timing of initiation, expansion, and warm-based activity of these glaciers cannot be determined at present, due to the lack of weathering surfaces and stratified exposures with multiple basal tills associated with advances from each distinct centre. On the Isthmus of AvaIon and the Placentia and Trepassey sub-peninsulas, and along the southern margins of the St. John's and Carbonear sub-peninsulas, formation of these glaciers preceded the development of the St. Mary's Bay ice centre, recognized by Henderson (1972). These initial ice masses are here assigned to Phase 1 of the glacial continuum, based on their occurrence prior to the extensive glacial event recognized as Phase 2.

During the subsequent Phase 2, glacial ice centred in St. Mary's Bay expanded to cover the southern two-thirds of the Avalon Peninsula, coalescing with other glaciers on the St. John's and Carbonear sub-peninsulas and along the Isthmus of Avalon. The superposition of Phase 2 erosional features over the initial glacial landforms, and the flow patterns indicated by Phase 2 features, suggest that this event represents the glacial maximum as recorded on the Avalon Peninsula. 

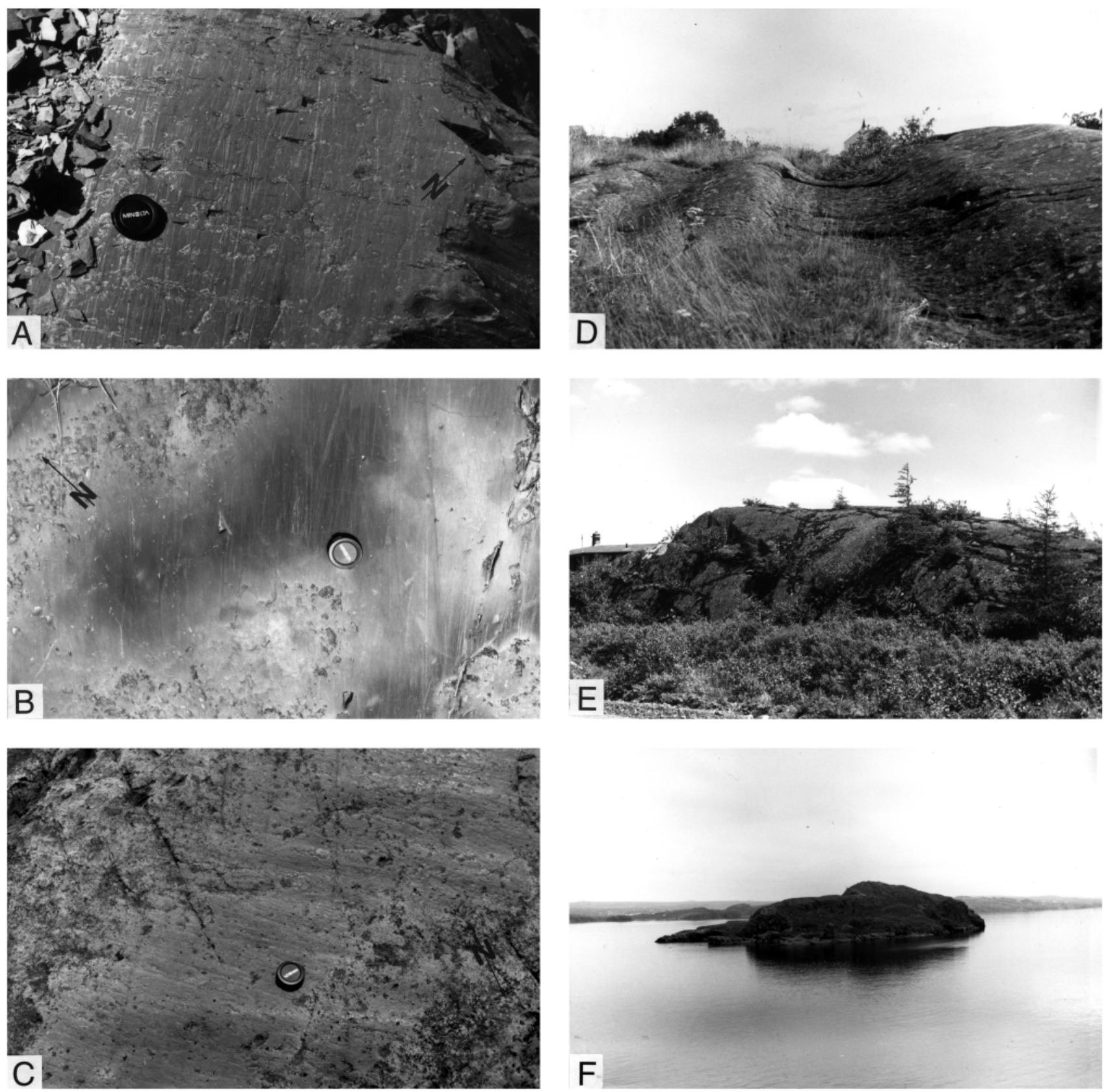

FIGURE 4. Typical erosional indicators of glacial flow, Avalon Peninsula. A: striations indicating multiple flow directions, from west-northwest to northwest, Heart's Desire (Catto, 1993); B: crossing striations indicating initial flow to north-east, cut by subsequent flow to east-southeast, Brigus area (Henderson, 1972; Catto, 1993); C: striations and streamlined features superimposed on stoss of eroded bedrock, indicating flow varying from easterly to southeasterly, Tors Cove area (Catto 1994a); D: subglacial grooves trending northeast on stoss of roche moutonnée, modified by later southeast flow, Thunderbolt Hill, Brigus (Catto 1993), photograph oriented looking northeast; $E$ : streamlined bedrock feature, indicating flow to northeast, Makinsons (Catto, 1992a), photograph oriented looking south; F: glacially modified bedrock indicating northeast flow, Fergus Island, Conception Bay (Catto, 1993), photograph oriented looking southeast.

Marques d'érosion indicatrices de l'écoulement glaciaire sur la péninsule d'Avalon. A) Stries donnant plusieurs directions de l'écoulement, de I'ONO au NO, Heart's Desire (Catto, 1993) ; B) entrecroisement de stries montrant un écoulement initial vers le NE, entrecoupé par un écoulement ultérieur vers l'ESE, région de Brigus (Henderson, 1972; Catto, 1993); C) stries et formes profilées surimposées sur la face exposée du substratum érodé, montrant un écoulement vers l'est et vers le SE, région de Tors Cove (Catto 1994a); D) cannelures sousglaciaires orientées vers le NE sur roches moutonnées, modifiées ultérieurement par un écoulement vers le SE, Thunderbolt Hill, Brigus (Catto, 1993), vue vers le NE;E) forme profilée dans le substratum, montrant un écoulement vers le NE, Makinsons (Catto, 1992a), vue vers le sud ; F) substratum érodé par les glaciers montrant un écoulement vers le NE, Fergus Island, Conception Bay (Catto, 1993), vue vers le SE. 
Subsequently, flow during deglaciation produced the striations and streamlined forms associated with Phase 3 . The absence of non-glacial sediments and weathering features pre-dating the Holocene suggests that all three phases represent a single continuous episode of glaciation.

\section{PHASE 1 - LOCAL ICE CENTRES}

The initial recorded glacial event recorded involved accumulation at several centres located along the axes of the sub-peninsulas and the isthmus. Ice expanded radially from these centres, resulting in glaciation of all parts of the Avalon Peninsula and of the southeastern part of the Isthmus (Fig. 6). Erosional features indicate periods of warm-based glacial activity.

The lack of numerical chronological data precludes direct correlation between individual features. Hence, the Phase 1 ice centres could have developed at different times throughout the Quaternary. Advances and retreats from each need not have been synchronous. Coalescence, where recognized, is based on the ice-flow indicators and the distribution of erratics resulting from the most recent event assigned to Phase 1, and may not reflect all glacial movement during the phase.

The Phase 1 centres, however, can be linked chronologically with respect to subsequent glacial events. Centres in the central and southern parts of the Avalon Peninsula predate the formation of the St. Mary's Bay Ice Centre during the Phase 2 maximum.

\section{Franks Pond Centre}

The Franks Pond Ice Centre developed in the centre of the Trepassey sub-peninsula. Ice radiated from Franks Pond to reach the Atlantic coast and the eastern shore of St. Mary's Bay. To the north and northwest, the ice coalesced with that from other sources. Evidence for eastward flow from Franks Pond is provided by igneous erratics, comprising $2 \%$ to $20 \%$ of the clasts in the diamictons at Cape Broyle, Ferryland, Aquaforte, Fermeuse, and Cappaheden. These erratics were derived from igneous units to the east and southeast of the Franks Pond centre.

Additional evidence that an ice centre was located to the east of St. Mary's Bay is provided by striations and streamlined bedrock outcrops (Catto, 1992a, 1994a, b). To the west and southwest of Franks Pond, most ice flow indicators are aligned southward and westward. Streamlined bedrock features indicating eastward flow are also present, but are generally smaller and less conspicuous than those associated with westward and southwestward flow. Along the coastline of St. Mary's Bay, sites with multiple striations and those marked by superimposition of small streamlined features upon larger roches moutonnées (Catto, 1992a; Catto and Thistle, 1993) suggest that the initial ice flow was directed westward and southwestward. Ice approached the coast of St. Mary's Bay from the east, and was deflected southwestward, parallel to the coast.

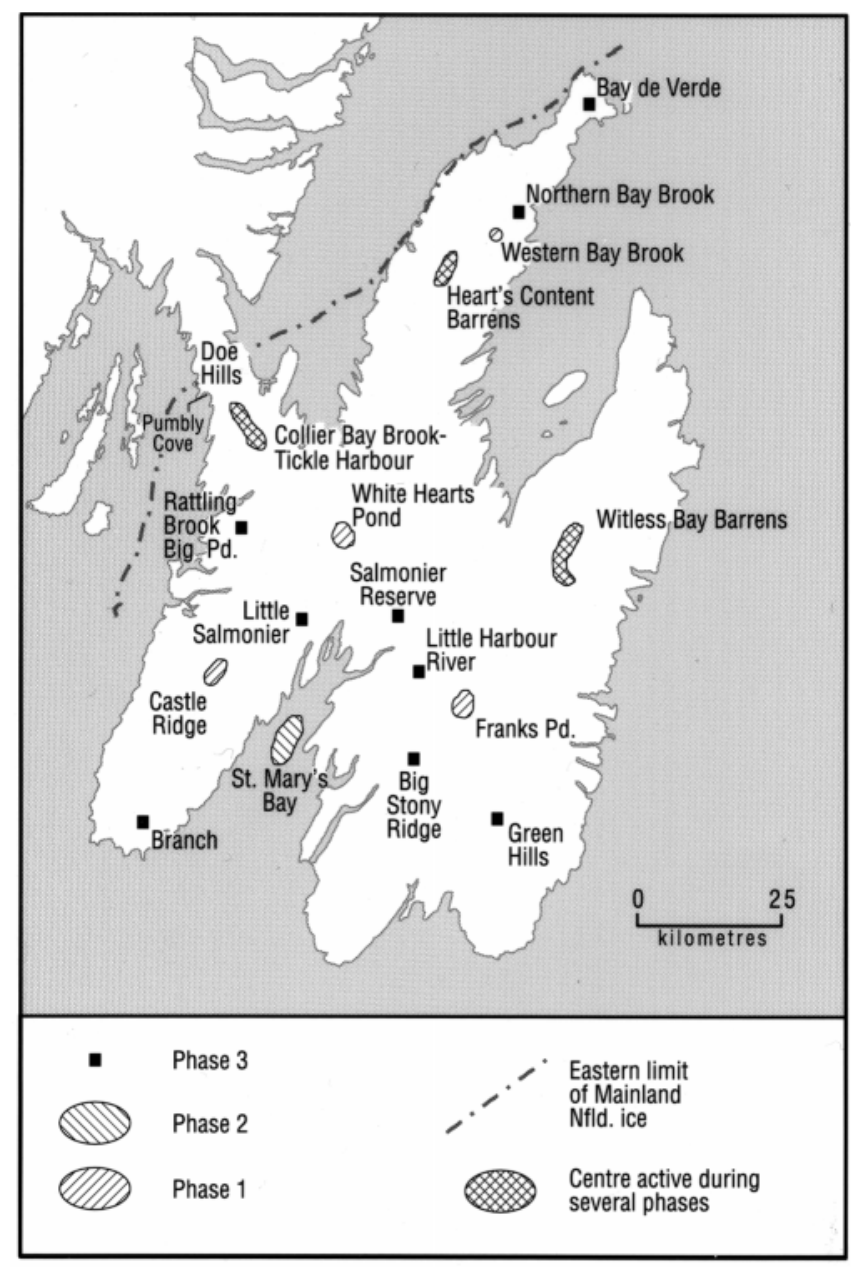

FIGURE 5. Ice Centres in the Avalon Peninsula and Isthmus. Les centres glaciaires de la péninsule et de l'isthme d'Avalon.

Southwestward flow from the centre of the Trepassey Sub-peninsula is also indicated by striations and streamlined features between Point LaHaye and Trepassey. Igneous erratics throughout the area east of Biscay Bay indicate transport from the ice centre. West of Biscay Bay, igneous clasts are not present in glacigenic Quaternary exposures. This distribution suggests that the centre of ice dispersion was located between the areas of igneous outcrop (east of Franks Pond) and Trepassey and St. Mary's Bays. Palaeozoic sedimentary rocks, which crop out along the west coast of St. Mary's Bay, are not present in glacigenic deposits.

\section{White Hearts Pond Centre}

An ice centre was located near White Hearts Pond. Flow is documented by numerous striations and streamlined erosional forms, and by isolated crag-and-tails, throughout the northern Placentia sub-peninsula and the southernmost Carbonear sub-peninsula (Catto, 1992a, 1993). Erratics derived from Palaeozoic rocks in diamictons located to the west and northwest of the Dildo Pond Anticline and White Hearts Pond, and their absence in diamictons to the northeast, also suggest flow from the White Hearts Pond area. 


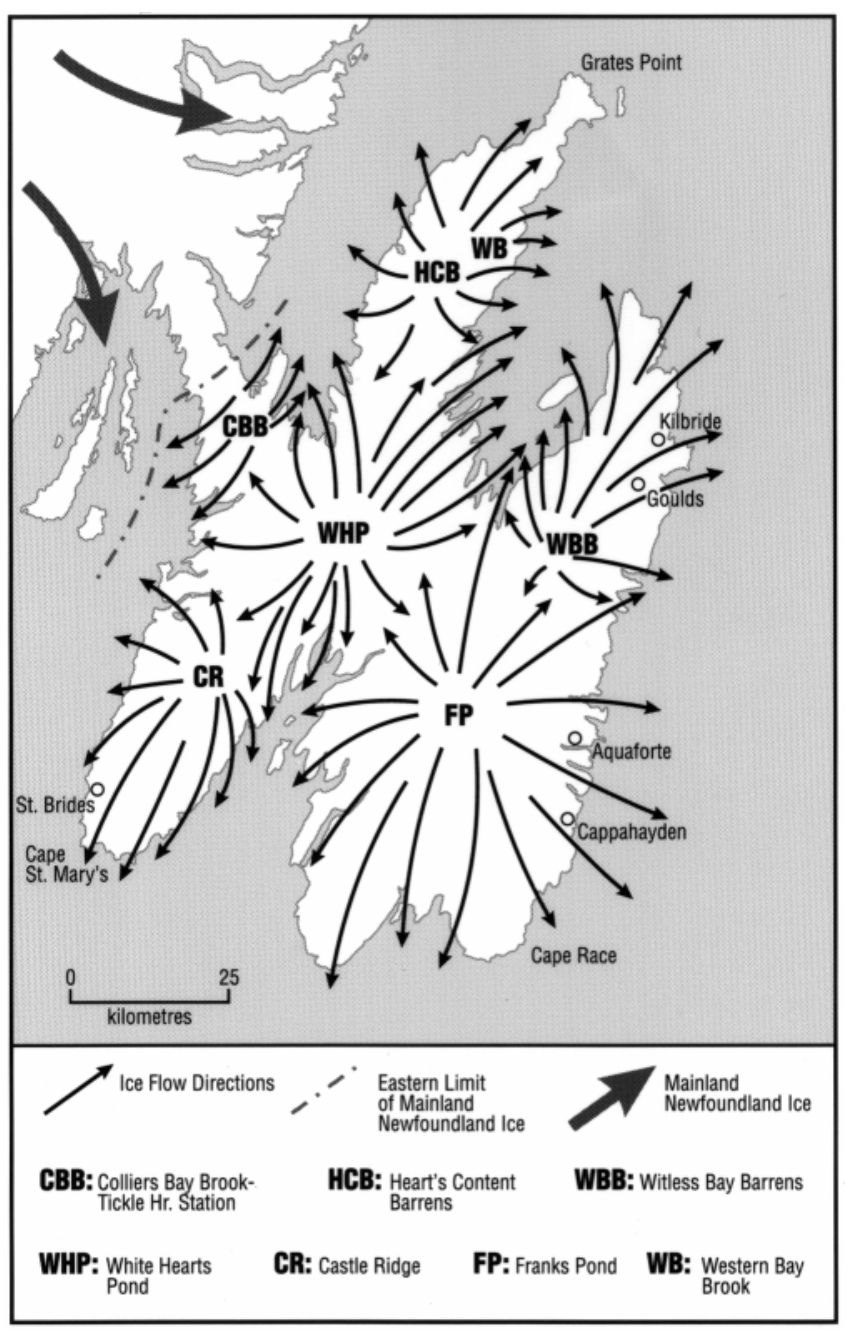

FIGURE 6. Ice Centres and Flow Directions, Phase 1, based on striation and streamlined landform data from Catto (1992a, 1993, 1994a) and Taylor et al. (1994).

Centres glaciaires et directions de l'écoulement au cours de la phase 1, à partir des données sur les stries et les formes profilées étudiées par Catto (1992a, 1993, 1994a) et Taylor et al. (1994).

Throughout the area, Rogen moraine crests are aligned east-west or northwest-southeast. The Rogen orientations suggest formation by northward flow in the areas north and west of White Hearts Pond, and by northeastward flow in the areas to the south, east, and northeast. The distribution of Palaeozoic clasts indicates that the development of the Rogen moraines of the White Hearts Pond area occurred subsequent to the deposition of the diamictons during the Phase 1 event. The orientations of the Rogen moraines thus are not indicative of the direction of ice flow during Phase 1.

\section{Witless Bay Barrens Centre}

An ice centre was located in the southern part of the St. John's sub-peninsula, in the Witless Bay Barrens. At some time during Phase 1, the Witless Bay Barrens ice expanded to coalesce with the Franks Pond ice near Tor's Cove and Black Ridge (Fig. 7).
The extent of Witless Bay Barrens ice can be assessed from the distribution of erratics derived from the granitic and mafic rocks which outcrop throughout the ice centre area. Igneous clasts are not found in diamicton outcrops west of the Avondale River, and this region was covered by ice from the White Hearts Pond Centre to the southwest (Fig. 8). The area between the Avondale River and Black Ridge, which contains granite-bearing diamictons, was glaciated during Phase 1 by northward-flowing ice from the Franks Pond Centre. To the east of Black Ridge, granitic and mafic clasts common in Quaternary deposits indicate that the Witless Bay Barrens ice transported large amounts of igneous material. Along the open Atlantic coast between Bay Bulls and Tor's Cove, granitic erratics form up to $10 \%$ of the clast assemblages in Quaternary diamictons. These erratics indicate flow from the Witless Bay Barrens centre, in conformance with the orientations of striations and streamlined erosional features (Catto, 1994a; Taylor et al., 1994).

The configuration of ice in the remainder of the St. John's sub-peninsula is more difficult to assess. Although basal ortho-tills in the northeastern sub-peninsula lack granitic erratics, diamictons interpreted as debris flow deposits throughout the area contain granitic clasts in concentrations varying from < 0.1 to $2 \%$ (Catto and Thistle, 1993; Catto and St. Croix, in press). Trace amounts of heavy minerals derived from igneous rocks are present in the sandy matrices of these diamictons.

The distribution of granitic pebbles and igneous minerals in the northern St. John's sub-peninsula suggests that ice flowed northward from the Witless Bay Barrens centre. Badly weathered ultramafic clasts may be derived from the Holyrood Intrusive Suite, or may have come from small, isolated ultramafic veins in the Cochrane Pond area (Batterson, 1988). The basal ortho-tills were derived from the underlying bedrock, and contained only local clasts. Subsequently, the overlying glacial ice deposited more distally transported sediments, including the granite-bearing diamictons.

\section{Carbonear Sub-Peninsula}

Glaciation of the Carbonear Sub-peninsula was marked by the development of two initial centres. The larger centre was located on the Heart's Content Barrens. Striations and streamlined erosional features indicate that ice radiated from this area, reaching the coast of Trinity Bay between Brownsdale and Heart's Delight, where it may have coalesced with ice from the White Hearts Pond centre to the south (Catto, 1993). Along the Conception Bay shore, Heart's Content Barrens ice overran the Carbonear embayment, extended at least as far north as Caplin Cove, and may have covered the entire northern sub-peninsula. Recognition of the regional extent of the Heart's Content Barrens ice is based exclusively on striations and streamlined erosional features, as no diagnostic bedrock units are exposed throughout the central Carbonear sub-peninsula. Overlapping striations suggest that a second ice centre was present in the headwaters of Western Bay Brook, to the northeast of the Heart'sContent 
Barrens centre (Catto, 1993). The Western Bay Brook Centre occupied a small region $\left( \pm 50 \mathrm{~km}^{2}\right)$, and was subsequently overwhelmed by the expanding Heart's Content ice.

The northward extent of ice on the Carbonear sub-peninsula during Phase 1 is uncertain. As erosion during the subsequent Phase 2 event was extensive, few traces of earlier glaciation remain in this region. The orientation of the oldest striations and streamlined erosional features north of Brownsdale and Caplin Cove is compatible with expansion of Heart's Content Barrens Ice to the northern tip of the subpeninsula. The limited evidence available is equally compatible with the existence of a linear ice divide extending along the spine of the sub-peninsula, or with the existence of a small Phase 1 centre on the inland barrens between Old Perlican and Caplin Cove.

Isthmus of Avalon

An ice centre developed on the Isthmus of Avalon, as indicated by the orientation of erosional features (Catto, 1992a). Ice flowed from the drainage divide between the headwaters of Collier Bay Brook and Tickle Harbour Station. Collier Bay Brook ice covered an area of approximately 300 $\mathrm{km}^{2}$ at its maximum. Along its southern margin, the glacier coalesced with the White Hearts Pond Centre ice.
Diamictons deposited by the isthmus ice are generally coarse-textured. In the Bellevue -Thornlea area, silty diamictons were derived from Cambrian siltstone and shale. Inland and along the Placentia Bay shore, the absence of clasts derived from the Cambrian strata suggests that glacial flow to the north of the drainage divide was northeastwards.

Granitic and mafic clasts are absent from diamictons in the southern and central Isthmus of Avalon. This area thus was not covered by ice originating from the mainland of Newfoundland. The lack of igneous erratics in the Collier Bay Brook and White Hearts Pond diamictons indicates that glacial ice did not cross Placentia Bay.

\section{Castle Ridge Ice Centre}

On the axis of the Placentia Sub-peninsula, Phase $1 \mathrm{gla}$ ciation was represented by the development of the Castle Ridge ice centre. Ice flowed from this centre towards Placentia Bay and St. Mary's Bay. Tongues of Castle Ridge ice reached the coastline of Placentia Bay through river valleys south of Placentia Roads. Initially, the ice was diverted parallel to the coastline, generally towards the southwest, producing striations at several localities (Catto, 1992a). Subsequently, as the glacier grew and thickened, flow was re-oriented westward, normal to the coast. Castle Ridge ice also flowed eastward towards St. Mary's Bay, coalescing

FIGURE 7. Phase 1 events, Holyrood - Avondale area. Ice flow directions are based on striations and streamlined landforms documented in Catto (1992a, 1993, 1994a), Catto and St. Croix (in press), and Taylor et al. (1994).

La phase 1, dans la région de Holyrood - Avondale. Les directions de l'écoulement sont fondées sur les stries et les formes profilées étudiées par Catto (1992a, 1993, 1994a), Catto et St. Croix (sous presse) et Taylor et al. (1994).

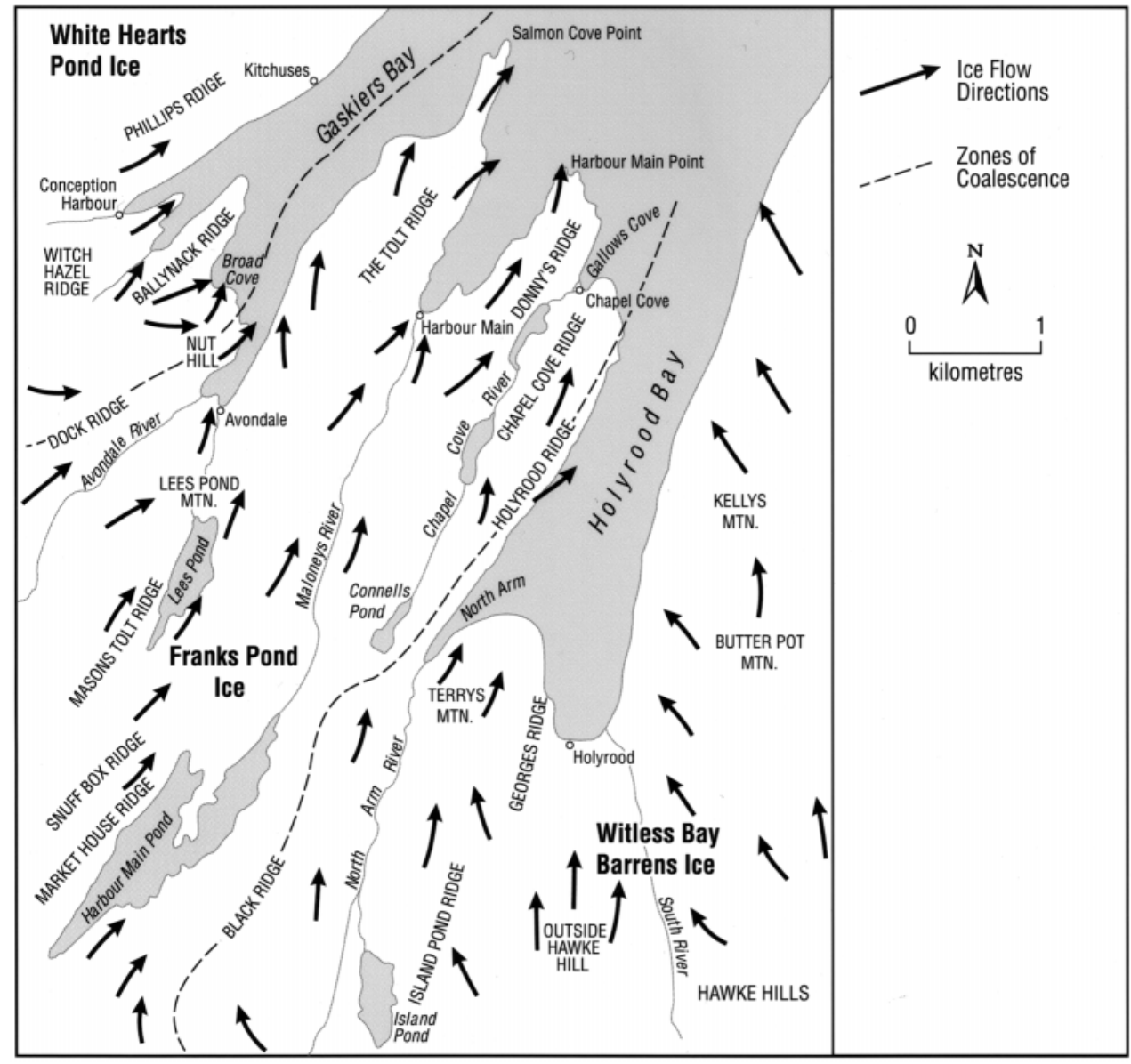




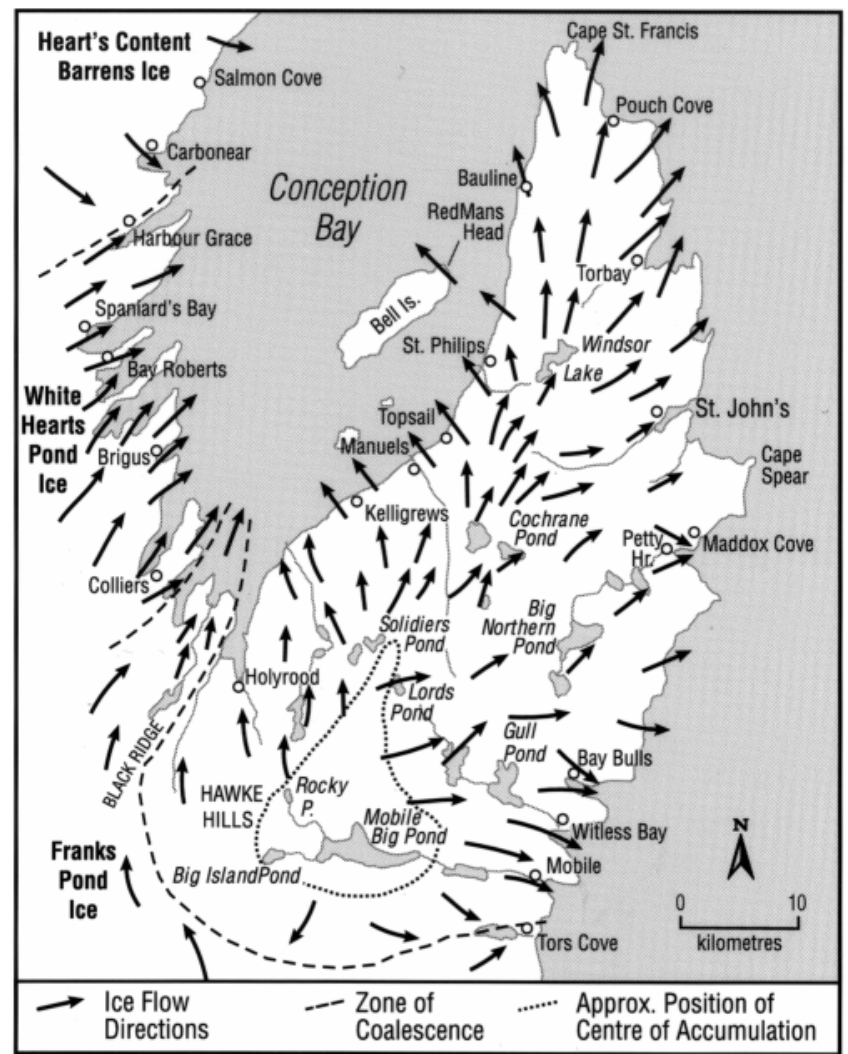

FIGURE 8. Witless Bay Barrens Ice Centre, initial phase. Ice flow directions are based on striations and streamlined landforms documented in Catto (1993, 1994a), Catto and St. Croix (in press), Catto and Thistle (1993), and Taylor et al. (1994). The boundary of the 'centre of accumulation' defines the source area for glacial ice, and does not represent an equilibrium line.

Le centre glaciaire de Witless Bay Barrens dans sa phase initiale. Les directions de l'écoulement sont fondées sur les stries et les formes profilées étudiées par Catto (1993, 1994a), Catto et St. Croix (sous presse), Catto et Thistle (1993) et Taylor et al. (1994). La limite du centre d'accumulation circonscrit le secteur d'origine des glaces et ne représente pas une ligne d'équilibre.

with White Hearts Pond ice flowing southwest along the structurally controlled topographic lows. The combined ice mass flowed southwestward along the margin of St. Mary's Bay.

\section{PHASE 2 - GLACIAL MAXIMUM}

Ice thickness and extent on the Avalon Peninsula and Isthmus reached a maximum during Phase 2, completely covering all areas affected by earlier Quaternary glaciation (Fig. 9). Ice extended offshore to the mouth of Conception Bay, and extended east of the present Atlantic coastline. All of St. Mary's and Placentia Bays were ice covered. Trinity Bay supported a vigorous ice stream, flowing across the Isthmus seaward to the moraine at its mouth, recognized by King and Fader (1992). Ice from the main island thus coalesced with Avalon ice in northern Placentia Bay, across the Isthmus, and through Trinity Bay, as postulated by Henderson (1972).

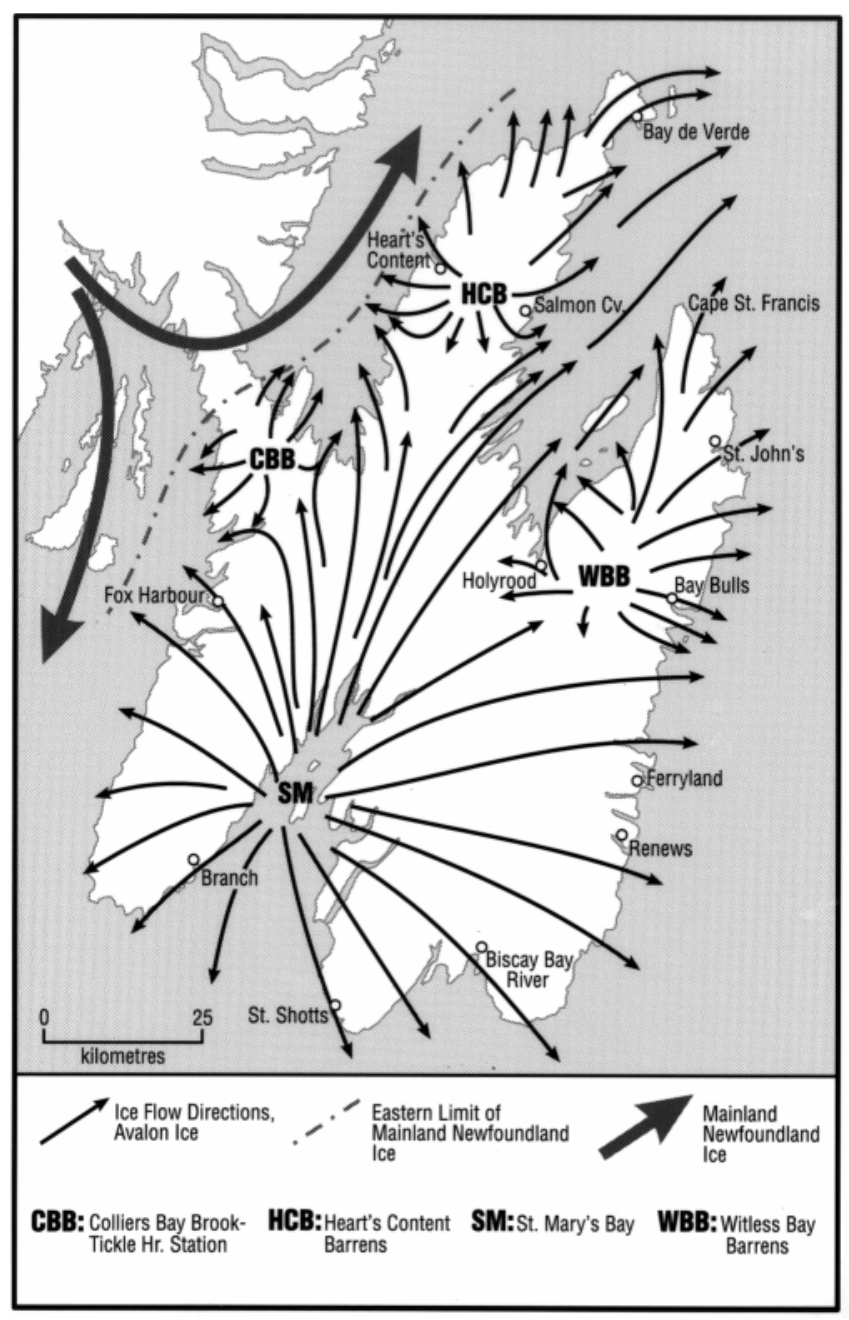

FIGURE 9. Ice Centres and Flow Directions, Phase 2 Maximum. Ice flow directions are based on striations and streamlined landforms documented in Henderson (1972), Vanderveer (1977), Catto (1992a, 1993, 1994a), Catto and Thistle (1993), and Taylor et al. (1994).

Centres glaciaires et directions de l'écoulement, au maximum de la phase 2. Les directions de l'écoulement sont fondées sur les stries et les formes profilées étudiées par Henderson (1972), Vanderveer (1977), Catto (1992a, 1993, 1994a), Catto et Thistle (1993), et Taylor et al. (1994).

\section{Witless Bay Barrens Ice Centre}

Witless Bay Barrens ice continued to cover the St. John's sub-peninsula. The growth of the ice produced gradual shifts in flow direction from the divide (Fig. 10). The change in extent of the ice source area affected the lithological composition of the diamictons produced by it. The northeastern part of the centre, east of the Topsail Fault, overlay Proterozoic sedimentary rock. Ice flowing from this source area thus did not contain granitic clasts, except for those which had previously been glacially eroded. Consequently, few granitic clasts were available for incorporation in Phase 2 diamictons. Granitic pebbles are extremely rare or are not present in diamicton units associated with the Phase 2 event along the eastern margin of the ice divide north of Bay Bulls, and in 


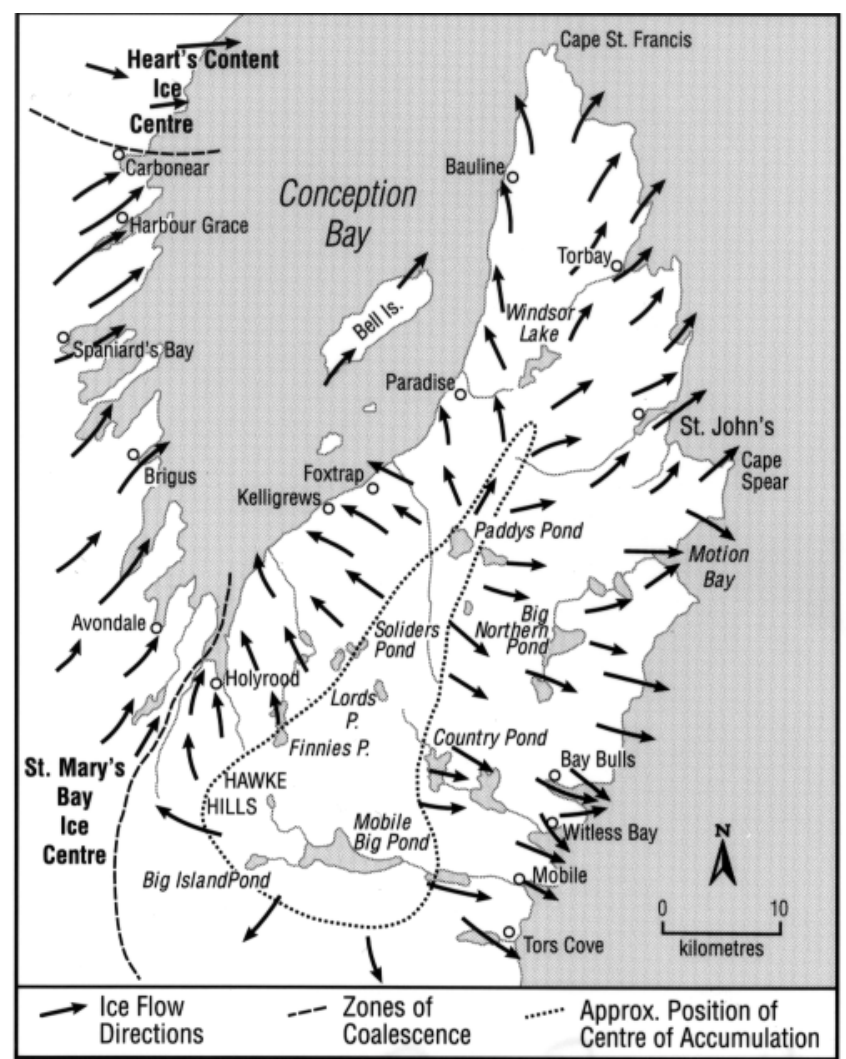

FIGURE 10. Witless Bay Barrens Ice Centre, Phase 2 Maximum. Ice flow directions are based on striations and streamlined landforms documented in Catto (1992a, 1993, 1994a), Catto and St. Croix (in press), and Taylor et al. (1994). The boundary of the 'centre of accumulation' defines the source area for glacial ice, and does not represent an equilibrium line.

Centre glaciaire de Witless Bay Barrens, au maximum de la phase 2. Les directions de l'écoulement sont fondées sur les stries et les formes profilées étudiées par Catto (1992a, 1993, 1994a), Catto et St. Croix (sous presse) et Taylor et al. (1994). La limite du centre d'accumulation circonscrit le secteur d'origine des glaces et ne représente pas une ligne d'équilibre glaciaire.

the area north and northeast of Paddy's Pond. The configuration of the Witless Bay Barrens Ice Centre during Phase 2 resembles the linear divide postulated by Henderson (1972).

\section{Heart's Content Barrens Ice Centre}

The Heart's Content Barrens Ice Centre persisted during Phase 2. Heart's Content Barrens ice covered the entire sub-peninsula north of Heart's Content and Salmon Cove (Fig. 11). The southern part of the centre of glaciation shifted to the east, away from the headwaters of Heart's Content Brook and toward Victoria.

Evidence for eastward migration of the ice divide's southern part is provided by striations exposed along the Heart's Content - Victoria highway (Catto, 1993). The oldest striation assemblage indicates ice flow to the southeast and east at these localities, originating from the area surrounding Stag Pond, Dog Hill Pond, and Long Pond. Striations and streamlined features to the west and northwest of these ponds indi-

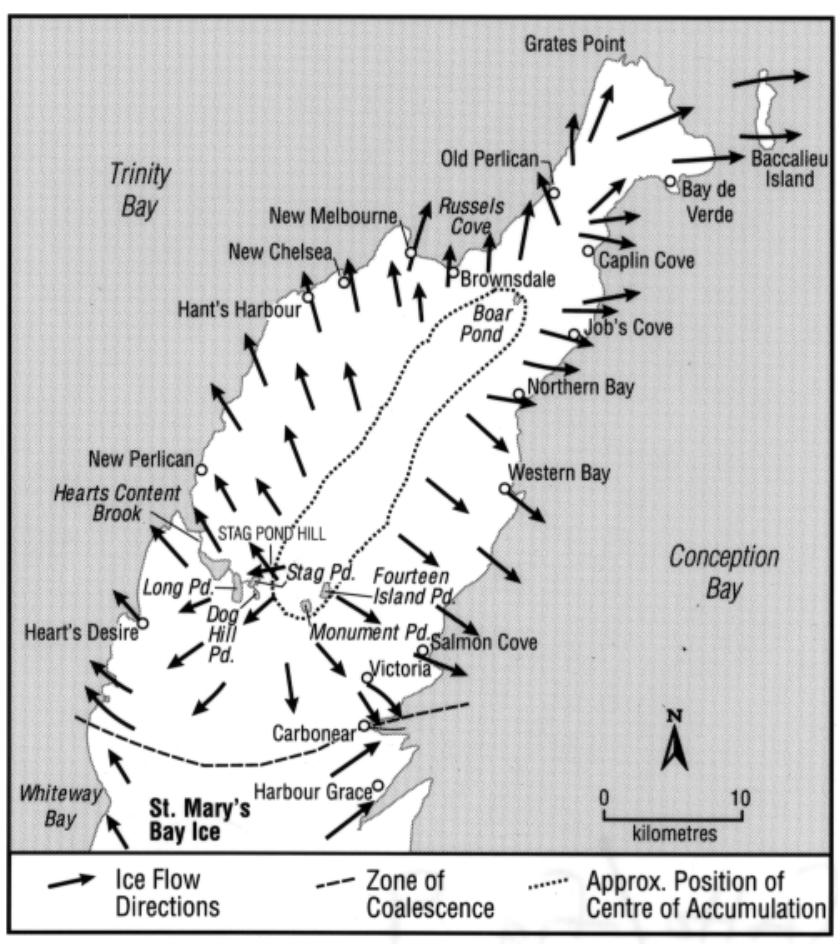

FIGURE 11. Heart's Content Barrens Ice Centre. Ice flow directions are based on striations and streamlined landforms documented in Henderson (1972), Catto (1993), and Taylor et al. (1994). The boundary of the 'centre of accumulation' defines the source area for glacial ice, and does not represent an equilibrium line.

Centre glaciaire de Heart's Content Barrens. Les directions de l'écoulement sont fondées sur les stries et les formes profilées étudiées par Henderson (1972), Catto (1993) et Taylor et al. (1994). La limite du centre d'accumulation circonscrit le secteur d'origine des glaces et ne représente pas une ligne d'équilibre glaciaire.

cate northwestward flow, suggesting that the ponds lay along the initial Phase 1 ice divide. Younger striations exposed to the east and southeast of the ponds indicate a shift in flow direction, to the west-southwest. These striations imply that the centre of ice flow had migrated from this area eastward across the striation sites, to a new location near Monument Pond-Fourteen Island Pond. Striations and streamlined features east of the shifting ice divide, along the Conception Bay shoreline, indicate that Phase 2 ice in this area continued to flow eastward. To the west of the divide, striations and streamlined features indicate that westward and northwestward flow persisted throughout Phase 2.

The ice divide extended northeastwards along the spine of the Carbonear sub-peninsula. Flow was to the southeast and east between Carbonear Bay and Caplin Cove. In the inland catchments of Western Bay Brook and Northern Bay Brook, the northeastward expansion of the source area caused shifts in flow direction from northeast to east and southeast.

To the north of Boar Pond, Phase 2 ice expanded seaward on both flanks of the drainage divide, and also expanded to cover the tip of the Carbonear sub-peninsula at Bay de Verde and Baccalieu Island. The configuration of the 
glacier in the area north of the Caplin Cove - Old Perlican Isthmus is somewhat uncertain at present. Striations and streamlined features suggest that glacial flow was dominantly northeastward along the axis of the sub-peninsula, diverging seaward along its margins. On the Caplin CoveOld Perlican Isthmus, striations and streamlined features on the coastal margins suggest seaward flow. Streamlined features in the interior indicating flow both parallel to and normal to the axis of the isthmus are present, but no examples of superposition exist which would enable assessment of the relative ages of the flow events. Therefore, it is uncertain at present whether the ice divide terminated in the vicinity of Boar Pond, or whether it extended northeast across the Caplin Cove-Old Perlican Isthmus to the Bay de Verde area.

Newfoundland Ice

The presence of ice from the main part of Newfoundland is readily recognizable in the western part of the Isthmus of Avalon. The presence of clasts derived from outcrops of Palaeozoic granite to the northwest (Swift Current area), and the silty texture of the diamictons resulting from the incorporation of marine sediments from Placentia Bay (Stehman, 1976; Willey, 1976), are considered to indicate ice flow from the Newfoundland mainland (Henderson, 1972; Vanderveer, 1977).

Newfoundland mainland ice coverage of the Isthmus of Avalon extended from Pumbly Cove east-northeastward to the Doe Hills and Tickle Bay (Fig. 12). Throughout the area north of this line, striations and bedrock streamlined features indicate that ice flowed across the isthmus, directly into Trin- ity Bay. Along the Trans-Canada Highway and the former route of the Newfoundland Railway, the transition from the zone covered by Isthmus of Avalon ice to that covered by Newfoundland mainland ice is marked by an abrupt shift from coarse sandy diamictons to fine, silty sand diamictons. The zone of transition is narrow, generally less than $1 \mathrm{~km}$ in width, and follows the positions established by Henderson (1972) and Vanderveer (1977). Ice flowed southward along the Central and Eastern Channels of Placentia Bay, across Merasheen, Long, and Red Islands, terminating in Placentia Bay. Newfoundland mainland ice coalesced with ice from the Isthmus and Avalon Peninsula in Trinity and Placentia Bays. Opposed flow directions between the Doe Hills and Pumbly Cove suggest that a narrow shear zone may have marked the interaction in the southwestern part of the Isthmus of Avalon.

Newfoundland ice entering Trinity Bay continued to flow to the northeast. The deep embayment acted to funnel the flow seaward, creating ideal conditions for the development of a large ice stream. The northern Isthmus of Avalon, with summit elevations to $230 \mathrm{~m}$ a.s.l., did not represent a significant obstruction to the development of the ice stream. Trinity Bay thus acted as a major conduit for Newfoundland ice. Large quantities of sediment, including granitic clasts, were transported seaward, resulting in the construction of a moraine at the grounding line at the mouth of Trinity Bay (King and Fader, 1992). During Phase 2, the ice stream was augmented by flow from the adjacent centres on the Avalon Peninsula, and thus granitic clasts were not deposited along the eastern coastline of Trinity Bay.

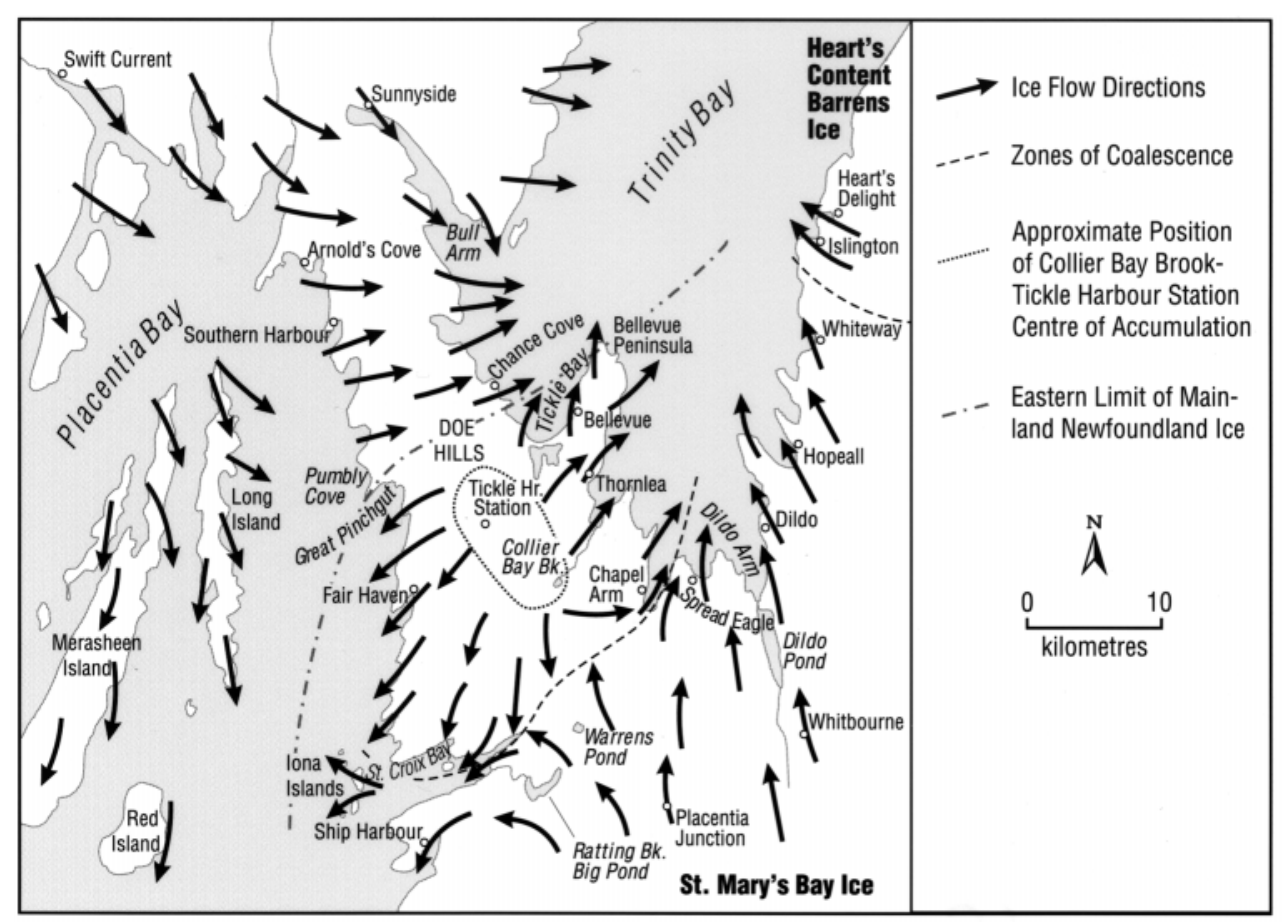

FIGURE 12. Glacial Flow, Isthmus of Avalon area. Ice flow directions are based on striations and streamlined landforms documented in Henderson (1972), Vanderveer (1977), Catto (1992a), and Taylor et al. (1994). The boundary of the "centre of accumulation' defines the source area for glacial ice, and does not represent an equilibrium line.

Écoulement glaciaire, région de l'isthme d'Avalon. Les directions de l'écoulement sont fondées sur les stries et les formes profilées étudiées par Henderson (1972), Vanderveer (1977), Catto (1992a, b) et Taylor et al. (1994). La limite du centre d'accumulation circonscrit le secteur d'origine des glaces et ne représente pas une ligne d'équilibre. 


\section{Collier Bay- Tickle Harbour Centre}

In the southern part of the Isthmus of Avalon, flow from the ice divide at Collier Bay - Tickle Harbour Station continued (Fig. 12). Ice flowed northward at Bellevue, Thornlea, Norman's Cove, and Chapel Arm, coalescing with Newfoundland mainland ice along its northwestern margin and with St. Mary's Bay ice at Chapel Arm. Along the position of the modern shoreline of Placentia Bay, isthmus ice continued to flow southwestward. The continued existence of the ice centre on the Isthmus was due in part to its establishment prior to the arrival of the Newfoundland mainland ice. The isthmus centre acted to accentuate the funnelling of the Newfoundland ice seaward towards Trinity Bay, thus diverting the flow. The existence of the Chapel Arm and Dildo Arm outlet valleys to the east, and the Long Harbour outlet valley to the south, diverted the expanding St. Mary's Bay glacier seaward.

\section{St. Mary's Bay Ice Centre}

The major event resulting from Phase 2 glaciation on the Avalon Peninsula involved the development of the St. Mary's Bay lce centre. At the Phase 2 maximum, this ice expanded to cover all parts of the Avalon Peninsula except the St. John's sub-peninsula, the northern Carbonear sub-peninsula, and the Isthmus of Avalon (Figs. 9 and 13). Evidence supporting the existence of the St. Mary's Bay centre, postulated by Henderson (1972), is extensive.
During Phase 2, the growth of the glacier in the offshore area resulted in a reversal of flow. Younger striations and superimposed streamlined bedrock features indicating eastsoutheast flow are present at Admirals Beach and Dalton Point (Fig. 14). Erosional indications of inland flow are also present at coastal exposures at O'Donnells, Double Road Point, LaHaye, Riverhead, and Gaskiers (Catto, 1992a). Clasts of the Gaskiers diamictite are located at Path End, Holyrood Pond, inland of the outcrop area of the stratum. Although the distribution of these clasts is compatible with eastward glacial transport from the coastal outcrops at Gaskiers, it could also be due to southwestward transport by Franks Pond ice from outcrops exposed along the Crossing Place River, which enters Holyrood Pond to the northeast. The Gaskiers diamictite clasts, therefore, cannot be considered as a definitive indicator of ice flow from St. Mary's Bay.

Additional evidence of eastward flow from St. Mary's Bay across the Trepassey sub-peninsula, however, is abundant. Throughout the source area of the Phase 1 Franks Pond ice, superimposed striations and streamlined bedrock landforms indicate that the area was overrun by ice from the west during Phase 2 (Catto, 1994a, b). The flow shifted from northeastward along the margin of St. Mary's Bay, to eastward in the Franks Pond area, to east-southeastward along the Atlantic Coast. At localities south of Renews, no evidence suggesting differing ice flow directions exists.
FIGURE 13. St. Mary's Bay Ice Centre. Ice flow directions are based on striations and streamlined landforms documented in Henderson (1972), Catto (1992a, 1994a), and Taylor et al. (1994).

Centre glaciaire de la baie St. Mary. Les directions de l'écoulement sont fondées sur les stries et les formes profilées étudiées par Henderson (1972), Catto (1992a, 1994a) et Taylor et al. (1994).

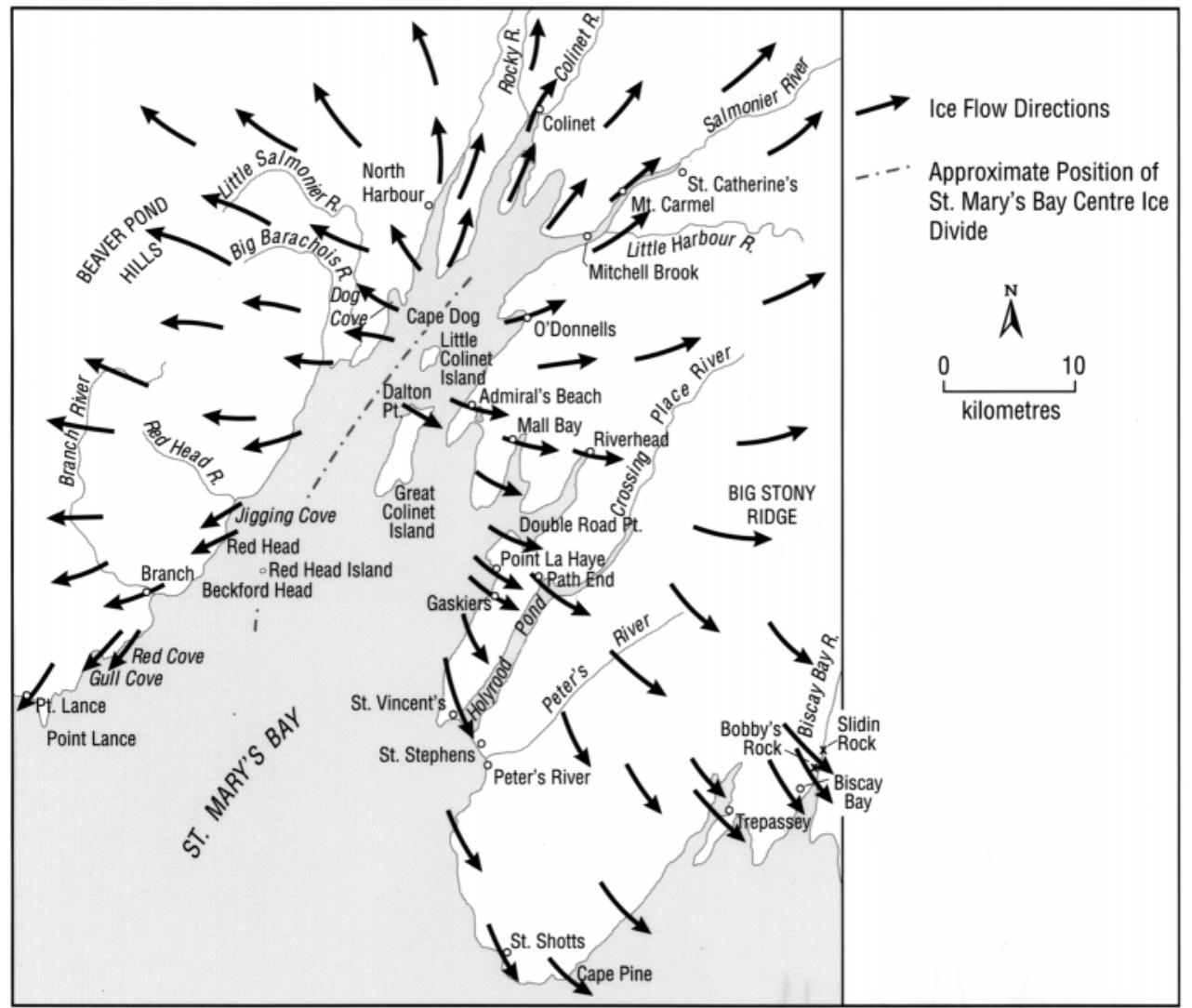




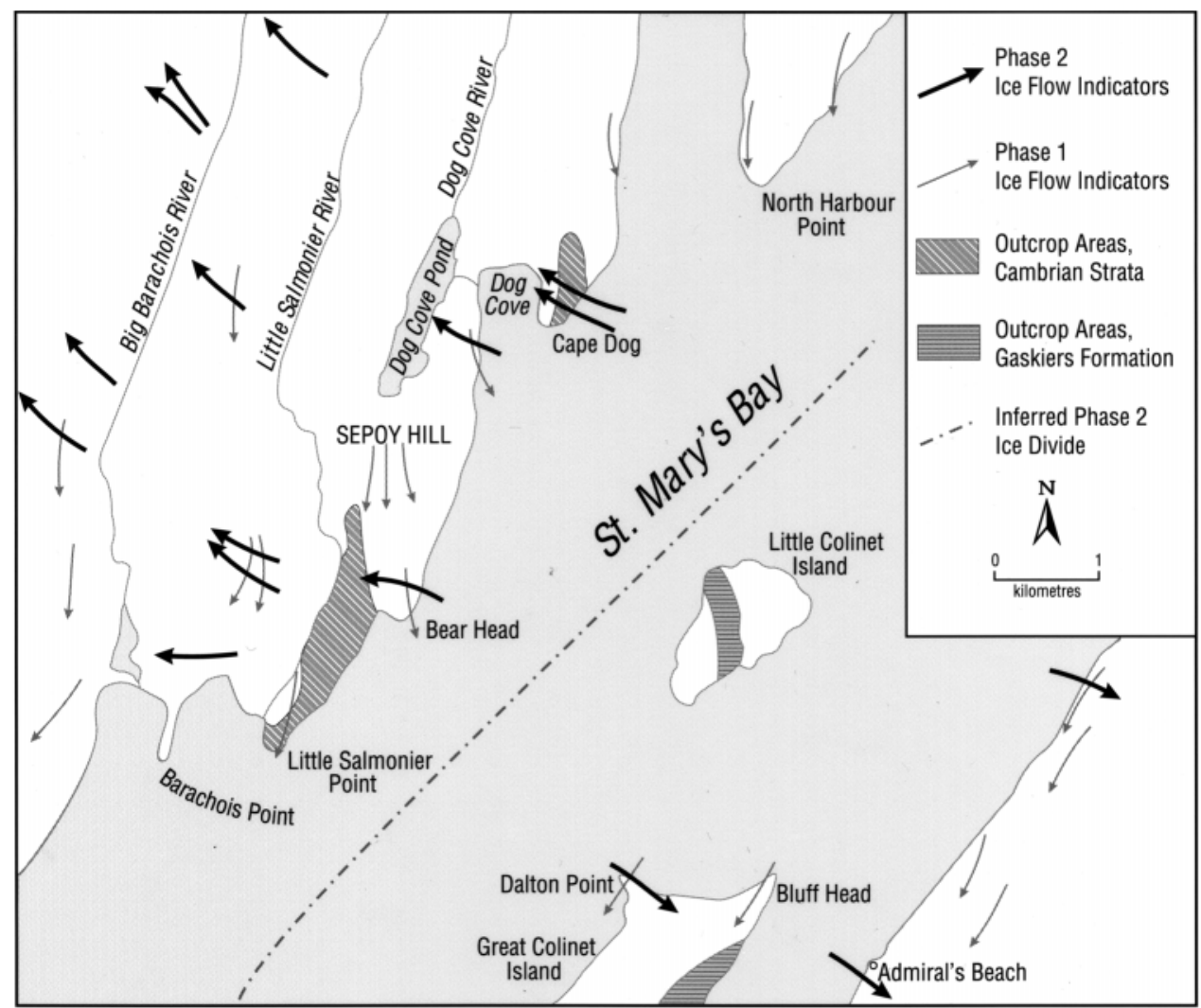

FIGURE 14. Ice Divide, St. Mary's Bay Ice Centre, Dog CoveLittle Colinet Island area. Ice flow directions are based on striations and streamlined landforms documented in Henderson (1972), Catto (1992a), and Taylor et al. (1994), and erratic clast distribution (discussed in text).

Ligne de partage des glaces, centre glaciaire de la baie St. Mary, région de Dog Cove-Little Colinet Island. Les directions de l'écoulement sont fondées sur les stries et les formes profilées étudiées par Henderson (1972). Catto (1992a) et Taylor et al. (1994) ainsi que sur la répartition des fragments d'erratiques (voir le texte).

At St. Shotts, in the southwestern part of the Trepassey sub-peninsula, striations (Catto, 1994a, b) indicate that an initial period of southwestern flow (from Franks Pond) was succeeded by flow to the southeast. Flow to the southeast, normal to the valley orientations, is also indicated by striations and streamlined features in the catchment area north of St. Shotts and Cape Pine. At Slidin Rock and Bobbys Rock, Biscay Bay River, striations produced by southward flow are overprinted by striae suggesting flow to the southsoutheast and southeast.

Along the western shoreline of St. Mary's Bay, evidence indicating landward flow is also common. On the western side of Dog Cove, basal diamicton containing clasts derived from the Placentia sub-peninsula is overlain by a second diamicton unit which contains red shale erratics derived from the Cambrian Bonavista Formation. The only outcrop of the Bonavista Formation in the area is located at Cape Dog, directly to the east of Dog Cove. The presence of the Bonavista Formation clasts in the diamicton thus indicates that ice moved westward from St. Mary's Bay across Cape Dog to the western side of Dog Cove, a supposition confirmed by the alignment of striations and streamlined features at Cape Dog (Fig. 14).

Landward movement of clasts from coastal exposures of Cambrian strata onto the outcrop areas of Late Proterozoic rocks has also been noted southwest of Dog Cove. Clasts derived from the Smith Point Formation have been found west of the valley of the Big Barachois River, indicating northwestward transport of at least $10 \mathrm{~km}$ across two inter- vening valleys. Similarly, Cambrian clasts have been transported southwestward and inland from Jigging Cove, Red Head, and Beckford Head. Striations and streamlined erosional features (Catto, 1992a) confirm the existence of landward flow from St. Mary's Bay along the Placentia subpeninsula.

Clasts from the Proterozoic Gaskiers diamictite are not present in the diamictons of the Placentia sub-peninsula. The absence of the Gaskiers material suggests that the ice divide was located to the west of the outcrop area of the Gaskiers diamictite. This requirement would position the ice divide to the west of Little Colinet and Great Colinet Islands (Fig. 14). The presence of southeastward-oriented striations at St. Shotts, and southwestward-oriented striations at Gull Cove, southwest of Branch, indicates that the ice divide extended beyond Red Head Island southwestwards in St. Mary's Bay to at least the vicinity of $46^{\circ} 50^{\prime} \mathrm{N}, 53^{\circ} 50^{\prime} \mathrm{W}$.

Flow from the St. Mary's Bay Ice Centre crossed the spine of the Placentia sub-peninsula, as indicated by superimposition of streamlined features in the vicinity of the initial Castle Ridge ice centre. In the Fox Harbour, Ship Harbour, and Long Harbour areas, striations indicating northwestward flow from the St. Mary's Bay centre are superimposed on earlier striae indicating southwestward flow from the White Heart's Pond centre during Phase 1. Northward and northeastward flow from the St. Mary's Bay ice centre, across the central region of the Avalon Peninsula occupied by the White Heart's Pond and Franks Pond centres, has been previously documented by Henderson (1972). 
Throughout the Whitbourne-Markland area, the direction of flow of the St. Mary's Bay ice approximately coincides with the flow orientation inferred from the crestal alignment of the Rogen moraines. Local deviations exist, however, particularly in areas where the Rogens are confined to valleys less than $300 \mathrm{~m}$ in width. In these areas, the orientations of Rogen crests indicate flow along the axis of the valley in the downslope direction. Glacial flow directions indicated by streamlined bedrock features and isolated crag-and-tails on adjacent ridges, however, locally deviate by $10^{\circ}-40^{\circ}$ azimuth from the Rogen orientations, and are generally consistent between adjacent ridges.

Ice from the St. Mary's Bay centre also expanded to the northeast, reaching Conception Bay and coalescing with the Witless Bay Ice Centre. Along the Trans-Canada Highway south of Avondale, the shift of flow direction was recorded by overlapping striations: the older indicative of Phase 1 northwestern flow from Franks Pond, the younger indicating Phase 2 northeastward flow (Catto, 1993).

Although the discharge of St. Mary's Bay ice into the embayments of Conception Bay may have generated ice streams flowing northeastward or northward, definitive evidence has not as yet been documented. On the northeastern tip of Bell Island, striations at Redmans Head indicate that glacial flow shifted from the northwestward orientation characteristic of Phase 1 to a northeastward alignment. This shift could represent the development of a large ice stream originating from glacial discharge at Holyrood and Gaskers Bays, flowing northeastward past Bell Island and thus overwhelming the seaward flow from the Witless Bay lce Centre, although collaborative evidence for this hypothesis is lacking.

\section{PHASE 3 - DEGLACIAL}

The subsequent phase of ice flow activity on the Avalon Peninsula was marked by the collapse of the major ice centres, and the initiation of flow from several short-lived local ice masses. Although this event was the most recent glacial phase to affect the entire Avalon Peninsula, its effect on the landscape was limited in most instances. Locally, however, glacial advances acted to re-distribute distinctive clasts, produce new striations, super-impose small streamlined features on the surfaces of older roches moutonnées, and deposit or modify diamictons. Although all Phase 3 features post-date those associated with the Phase 2 glacial maximum, deglaciation was not simultaneous throughout the Avalon Peninsula. The scarcity of numerical chronological data precludes direct assessment of the relative times of deglaciation at present.

\section{Maintenance and Collapse of the St. Mary's Bay Ice Centre}

The onset of deglaciation was marked by the disintegration of the St. Mary's Bay ice centre. Removal of the ice mass from St. Mary's Bay allowed re-establishment of smaller ice centres on the Trepassey and Placentia sub-peninsulas (Fig. 15).

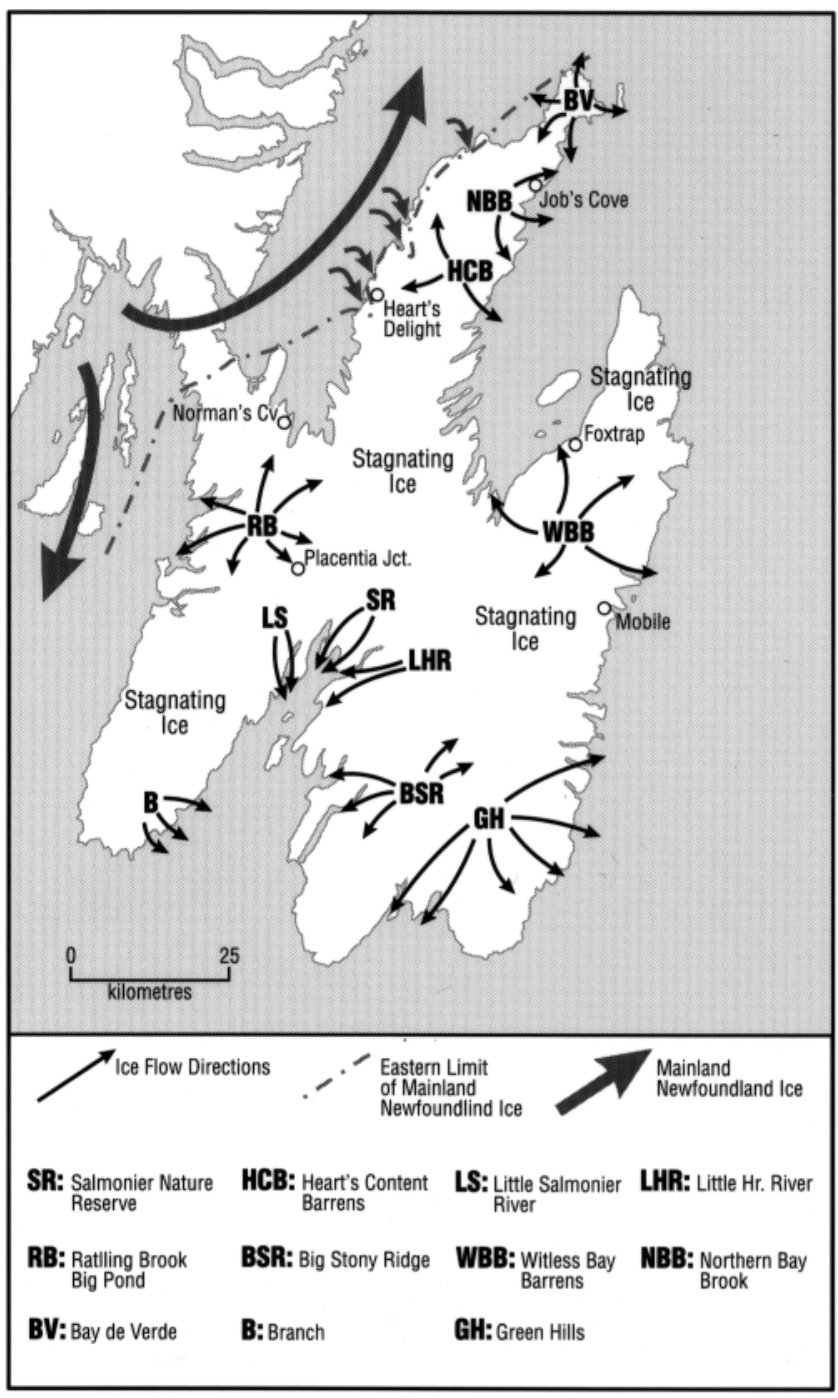

FIGURE 15. Ice Centres and Flow Directions, Deglacial Phase. Ice flow directions are based on striations and streamlined landforms documented in Catto (1992a, 1993, 1994a), Catto and St. Croix (in press), and Taylor et al. (1994).

Centres glaciaires et directions de l'écoulement, pendant la phase de déglaciation. Les directions de l'écoulement sont fondées sur les stries et les formes profilées étudiées par Catto (1992a, 1993, 1994a), Catto et St. Croix (sous presse) et Taylor et al. (1994).

The initiation and growth of a substantial ice cap in an offshore environment requires a lower sea level, and thus existence of the St. Mary's Bay Ice Centre depended upon sea levels substantially lower than that at present. At present, the modal depth of the bay south of Great Colinet Island is 120 $\mathrm{m}$, and some areas adjacent to the ice centre exceed $150 \mathrm{~m}$ in depth. The pattern of flow associated with the St. Mary's Bay centre, involving radial flow towards land masses on three sides (Fig. 9), also indicates that a lower sea level precluded excessive drawdown to the open ocean to the south.

An ice cap west of Great Colinet Island that was capable of surmounting the 275-300 m high summits of Castle Ridge and the Beaver Pond Hills on the Placentia sub-peninsula 
would require a minimum thickness of $450 \mathrm{~m}$. The requirement to overcome subglacial deformation induced by the load of the ice itself (cf. Boulton and Hindmarsh, 1987), coupled with evidence suggesting that the ice extended westward into Placentia Bay and eastward to the open Atlantic coastline (e.g. King and Fader, 1986), indicate that the St. Mary's Bay ice cap was substantially thicker than $450 \mathrm{~m}$ in its source area.

The thickness and areal extent of the St. Mary's Bay glacier, however, were not sufficient to overcome the glacio-isostatic distortion induced by the much larger Laurentide glaciers to the northwest, in Labrador. The pattern of raised marine terraces and beaches on the Avalon Peninsula and throughout Newfoundland (MacClintock and Twenhofel, 1940; Henderson, 1972; Grant, 1989; Liverman, 1994) indicates that glacio-isostatic deformation was controlled almost exclusively by Laurentide ice. In terms of sea level response to glacio-isostatic deformation, St. Mary's Bay lies within zone B of Quinlan and Beaumont $(1981,1982)$, marked by a short period of postglacial submergence followed by early and middle Holocene falling sea levels (Catto, 1994b; Liverman, 1994; Shaw and Forbes, 1995).

Sea level during the Late Wisconsinan Laurentide maximum along the Atlantic seaboard south and east of the Laurentide margin was at least $90 \mathrm{~m}$ lower than present (e.g. King and Fader, 1986; Amos and Miller, 1990; Piper et al., 1990; Wellner et al., 1993; Gipp, 1994). Sea-levels as low as $-110 \mathrm{~m}$ have been suggested for the area south of St. Mary's Bay (Miller and Fader, 1995). The maximum depth in the mouth of the bay, over St. Mary's Bank, is $65 \mathrm{~m}$. During the Late Wisconsinan maximum, St. Mary's Bank would be above sea level and the centre of the bay would be isolated from the ocean.

A decline in sea level of $90 \mathrm{~m}$ to $110 \mathrm{~m}$ would also cause the Grand Banks to the south and east to be exposed. This could permit the formation of a Grand Banks ice cap (Miller and Fader, 1995) which would act to further isolate St. Mary's Bay from the ocean. The absence of clasts derived from middle Palaeozoic and Mesozoic rock units present offshore and exposed on the Grand Banks indicates that the Grand Banks ice cap, if present, did not expand to reach the shorelines of the Avalon Peninsula. The St. Mary's Bay area would be completely isolated from the Atlantic Ocean during the Late Wisconsinan Laurentide maximum, even disregarding the effect of a Grand Banks ice cap.

Sea levels during both the glacial maximum and the subsequent deglaciation were controlled by the Laurentide ice, and the existence of the St. Mary's Bay ice centre was directly tied to the state of the Laurentide glaciers. Events leading to a retreat of Laurentide ice and a resultant rise in sea level would result in the destabilization of the southern margin of the St. Mary's Bay glacier. Rising sea levels would cause the ice mass in the bay to collapse, and would induce rapid drawdown. Glacial flow during Phase 3 thus resulted from the rise in sea level generated by changes in the extent of the Laurentide glaciers, rather than as a result of local or regional climatic fluctuations. The initiation of sea level rise preceded the Younger Dryas by a minimum of 3,000 years, whereas deglaciation on the Avalon Peninsula followed the Younger Dryas episode (Macpherson, 1996).

Along the margins of the bay, the collapse of the ice centre would be expected to induce a reversal in glacial flow, from landward to seaward. Glacial flow into St. Mary's Bay associated with the deglaciation of the embayment has been documented at several localities (Catto, 1992a, 1994a, b). At Branch and Red Cove, the youngest striations and superimposed streamlining on roches moutonnées indicate eastward flow, in contrast to the southwestward flow marking Phase 1 and the westward flow of Phase 2. Similar flow reversals are present in the Little Salmonier River and Salmonier Nature Reserve areas. In both these areas, the bayward flow is opposed both to the earlier northward-northeastward flow of Phase 2, and to the flow orientations inferred from the alignment of the numerous Rogen moraine crests. Several Rogen moraines in the Salmonier Nature Reserve area are marked by small erosional lineations indicating southward and southwestward flow on their surfaces, suggesting that formation preceded the Phase 3 flow event.

On the eastern side of St. Mary's Bay, flow westward into the embayment during Phase 3 is recorded by striations and streamlined features in the Little Harbour River catchment area. A second centre of bayward flow was located in the Big Stony Ridge area, east of Holyrood Pond. The Big Stony Ridge centre also was the source area for inland flow of glacial ice, towards the centre of the Trepassey sub-peninsula, and is the only Phase 3 centre surrounding St. Mary's Bay associated with flow away from the embayment.

Lagerlund et al. (1995) recognized a similar pattern of seaward glacial flow surrounding the western margins of the Baltic Sea, attributed to the accumulation of 'marginal domes' in the latter stages of glaciation. The absence of landward flow indicators associated with the Branch, Little Salmonier, Salmonier Nature Reserve, and Little Harbour River centres suggests that the ice in these areas was not sufficiently active or thick to form radially-flowing domes. The Big Stony Ridge ice, although it is associated with weak inland flow, is much smaller than the marginal domes of Lagerlund et al. (1995). It was influenced primarily by drawdown effects, rather than acting as a truly independent, radially-flowing marginal ice dome.

It is possible that the Phase 3 centres of ice flow surrounding St. Mary's Bay were linked laterally into a horseshoe-shaped ice divide. However, all of the centres identified here are located in the headwaters of rivers, and evidence of deglacial flow is confined to the valleys (with the exception of the Big Stony Ridge area). Glacial flow involved outlet glaciers entering the embayment from the remnants of the St. Mary's Bay ice cap surrounding the collapsed dome, with flow largely confined to the topographic lows.

\section{Marginal Ice Centres}

At least two smaller centres of ice flow persisted during deglaciation around the margins of the former St. Mary's Bay centre. On the Trepassey sub-peninsula, a small ice cap 
centred over the Green Hills was marked by flow to the south, southeast, and east. East of Long Harbour, on the Placentia sub-peninsula, an ice centre developed in the Rattling Brook Big Pond area. Ice from this centre created striations and streamlined bedrock forms indicating radial flow from Rattling Brook Big Pond, extending westward to Long Harbour, southwestward to Ship Harbour, southeastward towards Placentia Junction, and northward to Warren Pond. The areas covered by ice from both centres were small: approximately $200 \mathrm{~km}^{2}$ in the case of the better-defined Rattling Brook Big Pond ice mass. The existence of these centres indicates that glacial ice was disappearing from the Avalon Peninsula during Phase 3, allowing smaller centres to flow unimpeded.

\section{St. John's Sub-peninsula}

No evidence of distinctive deglacial ice centres exists on the St. John's sub-peninsula. The drawdown effects evident in other parts of the Avalon Peninsula, involving funnelling of dying masses of glacial ice through outlet valleys, are not evident. Sea level throughout the time of deglaciation was lower than at present in St. John's Harbour (Lewis et al., 1987; Liverman, 1994), and thus the glaciers were less susceptible to the development of seaward ice streams. Some minor drawdown effects are evident in the striation records along Mobile Bay, Bay Bulls, Witless Bay, and Motion Bay, where converging striations overprint the older Phase 2 striae aligned east-southeast (Catto, 1994a, b).

Lee-side diamicton deposits representing an areallyrestricted readvance associated with Phase 3 are present to the south of Foxtrap, Conception Bay South (Catto, and Thistle 1993; Catto and St. Croix, in press). The pattern of striations and streamlined features in the vicinity indicate that this event was approximately co-incident with a northwestward shift in the ice divide along the St. John's sub-peninsula. The migration of the ice divide reflects an increase in flow northwestward into Conception Bay.

In the area surrounding the Hawke Hills, the distribution of ice-contact gravelly diamictons and the clast macrofabric patterns within these units indicate that the summits of the hills were deglaciated before the margins. This hypothesis is re-enforced by the presence of poorly defined erosional channels paralleling the contours of several summits. Final deglaciation was categorized primarly by down-wasting (Macpherson, 1982, 1996).

\section{Carbonear Sub-peninsula}

Along the Carbonear sub-peninsula, the onset of deglaciation resulted in shifting ice flow directions. New centres developed in the headwaters of Northern Bay Brook and in the Bay de Verde area. West of Northern Bay, flow from the Northern Bay Brook centre was seaward. The Bay de Verde centre was marked by radial flow and the erosional overprinting of older features. Ice covered the $150 \mathrm{~km}^{2}$ area north of the Old Perlican - Caplin Cove Isthmus, but does not appear to have extended to Baccalieu Island.
In the central part of the Carbonear sub-peninsula, ice continued to flow towards Conception Bay from the Fourteen Island Pond area, in the eastern part of the Heart's Content Barrens. Shifting ice flow directions at Halfway House, Stag Pond Hill, and Salmon Cove indicate that ice flow was directed along topographic lows towards Conception Bay, and that the ice divide gradually migrated southeastward. This pattern suggests that drawdown by outlet glaciers discharging into Conception Bay was dominant during Phase 3. Flow towards Trinity Bay was reduced, as was flow northeastward oblique to the spine of the sub-peninsula was reduced, permitting the establishment of independent centres at Northern Bay Brook and in the Bay de Verde area.

Isthmus of Avalon and Trinity Bay

On the Isthmus of Avalon, eastward and northeastward flow of the Newfoundland mainland ice continued to cover the northern areas. The southern parts of the Isthmus probably remained ice-covered at this time, although no evidence for separate Phase 3 events exists.

Trinity Bay continued to act as a major outlet for Newfoundland mainland ice, and the ongoing process of deglaciation may have resulted in a temporary increase in flow velocity and volume. Outlet glaciers associated with the Greenland and Laurentide ice sheets have shown similar increases in activity associated with both changes in their source areas and with calving induced by sea-level rise (e.g. Kaufman et al., 1993; Clark, 1994). An increase in the activity of the Trinity Bay ice stream, coupled with the ongoing deglaciation of the Carbonear sub-peninsula and the southeastward migration of its centres of glaciation, is indicated by shifts in ice flow directions in Trinity Bay coastal sites. At Heart's Desire, Heart's Delight, Heart's Content, and New Perlican, the youngest striations indicate landward flow (Catto, 1993), in contrast to the seaward orientations characteristic of Phases 1 and 2. Flow directions are related to the configuration of the local topography, rather than being directed normal to the overall trend of the shoreline. The striations are located at elevations to $50 \mathrm{~m}$ a.s.I., more than 20 $\mathrm{m}$ above the maximum postulated marine limit (Henderson, 1972; Grant, 1989; Catto, 1994b; Liverman, 1994), and do not resemble the faint indentations associated with scouring by modern sea ice in the region.

\section{FINAL DEGLACIAL}

During the final stages of deglaciation, several remnants of the former ice caps existed across the Avalon Peninsula (Fig. 16). Supraglacial deposits produced upon deglaciation are common in the interior (Catto, 1992b). Most of the remnant ice masses lacked the ability to flow independently, and were ineffective as agents of erosion.

Evidence for independently flowing ice is confined to few areas. On the Isthmus of Avalon, striations and small streamlined forms overprinting older features indicate that separate ice caps persisted briefly along the drainage divide east of Little Harbour and Great Pinchgut. Small ice caps also produced erosional features at Chapel Arm Brook on the southern part of the isthmus; at Backside Cove, Bay de 


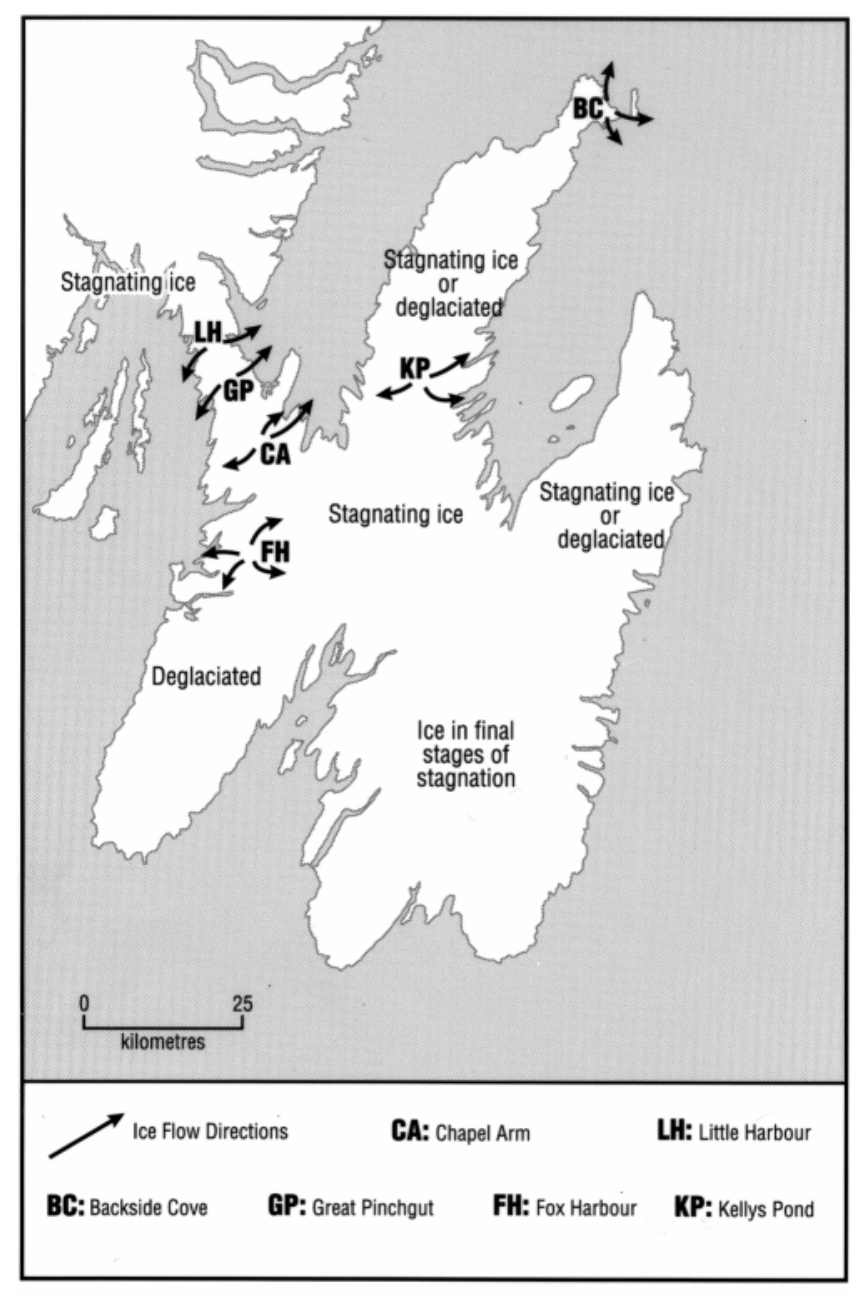

FIGURE 16. Ice Centres and Flow Directions during the final stages of deglaciation. Ice flow directions are based on striations and streamlined landforms documented in Catto (1992a, 1993, 1994a, b), and Taylor et al. (1994).

Centres glaciaires et directions de l'écoulement au cours des derniers stades de la déglaciation. Les directions de l'écoulement sont fondées sur les stries et les formes profilées étudiées par Catto (1992a, 1993, 1994a, b) et Taylor et al. (1994).

Verde; and at Kelly's Pond, Carbonear sub-peninsula, but none affected an area larger than $10 \mathrm{~km}^{2}$. The largest of the centres, in the Fox Harbour area, covered approximately 30 $\mathrm{km}^{2}$.

\section{CHRONOLOGY}

Numerical chronological evidence is scarce throughout eastern Newfoundland, particularly on the Avalon Peninsula. Although establishment of a relative chronology of the phases of the most recent glaciation is possible, the absence of differential weathering features on the striated and streamlined surfaces, such have been reported elsewhere in Newfoundland (e.g. Klassen and Henderson, 1992), makes determination of the time elapsed between each glacial phase impossible at present. The absence of weathering features suggests that the phases are part of a continuum of glacial activity, not marked by intervening deglaciations.

No direct indication of the date of initiation of glaciation on the Avalon Peninsula exists, and no pre-glacial deposits have been recognized. Phase 1, therefore, could represent any part or all of the period between the initiation of glaciation and the Last Glacial Maximum. In addition, the individual ice centres of Phase 1 need not have developed synchronously, and need not have been characterized exclusively by warm-based activity throughout their lifetimes. However, the absence of weathering features and non-glacial deposits indicates that the conclusion of Phase 1 was followed without intervening deglaciation by Phase 2. This relationship of Phase 1 in an apparent continuum with the glacial maximum of Phase 2 suggests a Wisconsinan age for the transition between the phases. The time of initiation of any part of Phase 1 glaciation, however, remains uncertain.

All parts of the Avalon Peninsula were glaciated during Phase 2 time. This phase was marked by the development of the St. Mary's Bay ice centre. As this centre could not develop until sea level had fallen to at least $60 \mathrm{~m}$ below its present value, its existence is directly associated with the drop in sea level precipitated by the widespread glaciation of the Northern Hemisphere, particularly the development of the Laurentide and Fennoscandian continental glaciers. The initiation and duration of the St. Mary's Bay ice centre, therefore, co-incide with the period of maximum glacial activity of the Laurentide ice in eastern Canada.

A Late Wisconsinan age for the conclusion of Phase 2 is suggested by the absence of weathering features or subaerial deposits separating the Phase 2 landforms and sediments from those of Phase 3. The time of initiation of Phase 2 , however, is less certain. Although the Late Wisconsinan maximum of the Laurentide Inlandsis occurred ca. 22,000 16,000 BP (Dyke and Prest, 1987; Grant, 1989; Vincent, 1989; Piper et al. , 1990), the St. Mary's Bay ice centre could have begun to accumulate as soon as relative sea level fell below approximately $-65 \mathrm{~m}$. Thus, the initiation of Phase 2, and the duration of the preceding Phase 1, could have preceded the Late Wisconsinan Laurentide maximum.

Phase 3 is defined on the basis of the collapse of the St. Mary's Bay ice centre, which was caused by rising sea levels consequent upon retreat of the Laurentide ice. This relationship suggests that Phase 3 glaciation began on the Avalon Peninsula at the time that Laurentide ice started to retreat along the eastern seaboard of North America, an event that commenced ca. 15,000 - 14,000 BP (Dyke and Prest, 1987; Piper et al. , 1990).

The timing of deglaciation was driven by climate and glaciological changes that affected the Laurentide glaciers, rather than by the effects of climate fluctuations on the local environment. Flow into St. Mary's Bay and Conception Bay, migration of the ice divides on the Carbonear and St. John's sub-peninsulas, and the development of the Trinity Bay Ice Stream, were responses to changes in sea level induced beyond the Avalon Peninsula. Palynological investigations 
on the Avalon Peninsula (Macpherson, 1996) indicate that deglaciation post-dated the Younger Dryas episode. Thus, there is no evidence to link Phase 3 events on the Avalon Peninsula with the climatic oscillations represented by the Younger Dryas or other amphi-Atlantic events recorded elsewhere in Atlantic Canada (Stea and Mott, 1993; Levesque et al. 1993; Cwynar et al., 1994; Mott and Stea, 1995), including the mainland of Newfoundland (Anderson and Macpherson, 1994; Wolfe and Butler, 1994; Macpherson, 1995).

The final deglaciation of the Avalon Peninsula is constrained by a ${ }^{14} \mathrm{C}$ date of $10,100 \pm 250 \mathrm{BP}$ (GSC-3136) from Golden Eye Pond in the Hawke Hills, the oldest of 12 basal ${ }^{14} \mathrm{C}$ dates (Macpherson 1995, 1996). The time required for vegetation to reach and become established on the Avalon Peninsula suggests that the actual date of deglaciation was at most a few centuries prior to 10,100 $\pm 250 \mathrm{BP}$ (Macpherson, 1996). Strict quantitative assessment of ${ }^{14} \mathrm{C}$ dates in the 10,000 $-11,000$ BP age range is complicated by evidence of anomalies in the ${ }^{14} \mathrm{C}$ record (Bard and Broecker, 1992; Sulerzhitsky, 1997).

\section{SUMMARY}

Detailed analysis of ice flow indicators on the Avalon Peninsula and the Isthmus of Avalon (Catto 1992a, 1993, 1994a) has resulted in the recognition of three phases in a continuum of glaciation. Phase 1 was marked by the accumulation of ice at centres located along the axes of the major subpeninsulas, and by expansion seaward. During Phase 2, lowered sea level allowed the development of the St. Mary's Bay ice centre, as recognized by Henderson (1972). Ice expanded from St. Mary's Bay, covering most of the Avalon Peninsula, while independent centres persisted in the St. John's and Carbonear sub-peninsulas and on the Isthmus of Avalon. Ice from the Newfoundland mainland overran the northern part of the Isthmus, and extended as an ice stream into Trinity Bay.

Rising sea levels, triggered by the retreat of the Laurentide ice, resulted in the destabilization of the Avalon glaciers. Phase 3 was marked by the collapse of the St. Mary's ice centre, rapid drawdown into St. Mary's and Conception Bays, and the persistence of the Trinity Bay ice stream. Continued deglaciation was punctuated by minor events. Deglaciation of the Avalon Peninsula began at some time prior to $10,100 \pm 250 \mathrm{BP}$.

This study has demonstrated the importance of local conditions in the generation of glacial flow patterns, and the necessity for detailed field mapping and analysis. The AvaIon glaciers were controlled by regional and hemispheric events, such as those to which the Laurentide glaciers responded, but the mode of response was not identical to that of glaciers in other regions of Atlantic Canada. Correlation of glacal episodes on a regional scale will require understanding of the different dynamic responses initiated by a single event.

\section{ACKNOWLEDGMENTS}

This paper co-incides with the fortieth anniversary of the commencement of E.P. Henderson's pioneering study of the Avalon Peninsula, work which has provided a sound and much-appreciated foundation for subsequent efforts. Throughout the eight years of this research, I have greatly benefited from insightful field and office discussions and throughtful reviews from Dave Liverman, Joyce Macpherson, Nat Rutter, John Shaw, Trevor Bell, the participants in the International Association of Geomorphologists Field Trip A-7 (1993), and those in the joint CANQUA/CGRG Avalon Field Trip (1995), and many other Quaternarists. Upon my arrival in Newfoundland, Dave Proudfoot introduced me to sites along the Southern Shore and Trinity Bay; his passing is greatly regretted. The paper was substantially improved through the dedicated reviews of Art Dyke and Bernard Hétu, and an anonymous reviewer of Géographie physique et Quaternaire. Thanks are due for field and technical assistance to Ralph House, Curtis Pennell, and especially Gail Catto. Cartographic services were provided by the Memorial University Cartographic Laboratory. This research was supported in part by grants from the Natural Sciences and Engineering Research Council of Canada.

\section{REFERENCES}

Amos, C.L. and Miller, A.A.L., 1990. The Quaternary stratigraphy of southwest Sable Island Bank, eastern Canada. Geological Society of America Bulletin, 102: 915-934.

Anderson, T.W. and Macpherson, J.B., 1994. Wisconsin Late-glacial environmental change in Newfoundland: A regional review. Journal of Quaternary Science, 9: 171-178.

Astakhov, V., 1997. Late Glacial Events in the Central Russian Arctic. Quaternary International, 41/42: 17-25.

Bard, E. and Broecker, W.S., 1992. The Last Deglaciation: Absolute and Radiocarbon chronologies. NATO ASI Series. Series 1: Global Environmental Change, 2, Springer, Berlin.

Batterson, M.J., 1988. Guidebook, Canadian Institute of Mining and Metallurgy field trip to the Burin Peninsula, 1988. Unpublished Guidebook, Geological Survey Branch, Department of Mines and Energy, Government of Newfoundland and Labrador.

Batterson, M.J. and Liverman, D.G.E., 1995. Landscapes of Newfoundland and Labrador: A collection of aerial photographs. Geological Survey Branch, Ministry of Natural Resources, Government of Newfoundland and Labrador.

Bouchard, M.A., 1989. Subglacial landforms and deposits in central and northern Québec, Canada, with emphasis on Rogen moraines. Sedimentary Geology, 62: 293-308.

Boulton, G.S. and Hindmarsh, R.C.A., 1987. Sediment deformation beneath glaciers: Rheology and geological consequences. Journal of Geophysical Research, 92: 9059-9082.

Brookes, I.A., 1982. Ice Marks in Newfoundland: A history of ideas. Géographie physique et Quaternaire, 36: 139-163.

1989. Glaciation of Bonavista Peninsula, northeast Newfoundland. The Canadian Geographer, 33: 2-18.

Broster, B. E., Munn, M.D. and Pronk, A.G., 1997. Inferences on glacial flow from till clast dispersal, Waterford area, New Brunswick. Géographie physique et Quaternaire, 51: 29-39.

Catto, N.R., 1992a. Surficial geology and landform classification maps for the southwest Avalon Peninsula. Newfoundland Department of Mines and Energy, Geological Survey Branch, open file 2186. 
1992b. Supraglacial sedimentation in continental glacial environments Dalarna (Sweden) and Avalon, Newfoundland (Canada): A comparative analysis. Sveriges Geologiska Undersökning, Ser. Ca. 81: 81-86.

1993. Surficial Geology and Landform Classification, northwestern Avalon Peninsula. Government of Newfoundland and Labrador, Department of Mines and Energy, Open File. 001 N/535.

1994a. Surficial Geology and Landform Classification, eastern Avalon Peninsula. Government of Newfoundland and Labrador, Department of Mines and Energy, Open File 001 N/536.

1994b. Coastal Evolution and Sea Level Variation, Avalon Peninsula Newfoundland: Geomorphic, Climatic, and Anthropogenic Variation. In P.G. Wells and P.J. Ricketts, eds, Coastal Zone Canada 1994: CoOperation in the Coastal Zone, Bedford Institute of Oceanography, Dartmouth, Conference Proceedings, 4: 1785-1803.

Catto, N.R. and St. Croix, L., in press. Urban geology of St. John's, Newfoundland. In P.F. Karrow and O.L. White, eds., Urban Geology of Canadian Cities. Geological Association of Canada, Special Paper 42.

Catto, N.R. and Thistle, G., 1993. Geomorphology of Newfoundland. International Geomorphological Congress, Guidebook A-7, Memorial University of Newfoundland.

Chalmers, R., 1895. Report on the surface geology of eastern New Brunswick, northwestern Nova Scotia, and a portion of Prince Edward Island. Geological Survey of Canada, Annual Report, 7, part M.

Chamberlin, T.C., 1895. Notes on the glaciation of Newfoundland. Geological Society of America Bulletin, 6: 467.

Clark, C.D., 1993. Mega-scale glacial lineations and cross-cutting ice-flow landforms. Earth Surface Processes and Landforms, 18: 1-29.

Clark, P.U., 1994. Unstable behaviour of the Laurentide Ice Sheet during the last glacial-interglacial transition. Quaternary Research, 41: 19-25.

Cogley, J.G., Aikman, M. and Stokes, D.J.A., 1997. Allochthonous sediment in till near a lithological boundary in central Ontario. Géographie physique et Quaternaire, 51: 17-27.

Coleman, A.P., 1926. Pleistocene of Newfoundland. Journal of Geology, 34: 193-223.

Colman-Sadd, S.P., Hayes, J.P. and Knight, I., 1990. Geology of the island of Newfoundland. Map 90-01, Geological Survey Branch, Department of Mines and Energy, Government of Newfoundland and Labrador

Cumming, E.H., Aksu, A.E. and Mudie, P.J., 1992. Late Quaternary glacial and sedimentary history of Bonavista Bay, northeast Newfoundland. Canadian Journal of Earth Sciences, 29: 222-235.

Cwynar, L.C, Levesque, A.J. and Mayle, F.E., 1994. Wisconsin Late-glacial environmental changes in New Brunswick: A regional synthesis. Journal of Quaternary Science, 9: 161-164.

Dardis, G.F., McCabe, A.M. and Mitchell, W.I., 1984. Characteristics and Origins of lee-side stratification sequences in Late Pleistocene drumlins, Northern Ireland. Earth Surface Processes and Landforms, 9: 409-424.

Dreimanis, A., 1993. Water-eroded crescentic scours and furrows associated wiith subglacial flutes at Breidamerkurjökull, Iceland. Boreas, 22: 110-112.

Dyke, A.S. and Prest, V.K., 1987. Late Wisconsinan history of the Laurentide Ice Sheet. Géographie physique et Quaternaire, 41: 237-263.

Eyles, N. and Eyles, C., 1989. Glacially-influenced deep-marine sedimentation of the Late Precambrian Gaskiers Formation, Newfoundland, Canada. Sedimentology, 36: 601-620.

Fisher, T. and Shaw, J., 1992. A depositional model for Rogen moraine, with examples from the Avalon Peninsula, Newfoundland. Canadian Journal of Earth Sciences, 29: 669-686.

Flint, R.F., 1940. Late Quaternary changes of sea level in western and southern Newfoundland. Geological Society of America Bulletin, 51: 17571780 .

Gipp, M.R., 1994. Late Wisconsinan deglaciation of Emerald Basin, Scotian Shelf. Canadian Journal of Earth Sciences, 31: 554-566.
Gosse, J.C., Grant, D.R., Klein, J and Lawn, B., 1995. Cosmogenic 10Be and $26 \mathrm{Al}$ constraints on weathering zone genesis, ice cap basal conditions, and Long Range Mountain (Newfoundland) Glacial History. CANQUA abstracts CA19, CANQUA/CGRG 95, St. John's, Newfoundland.

Grant, D.R., 1974. Prospecting in Newfoundland and the Theory of multiple shrinking ice caps. Geological Survey of Canada, Paper 74-1B: 215-216.

1977. Glacial Style and ice limits, the Quaternary Stratigraphic record, and changes of land and ocean level in the Atlantic Provinces, Canada. Géographie physique et Quaternaire, 31: 247-260.

1989. Quaternary geology of the Atlantic Appalachian region of Canada In R.J. Fulton, ed., Quaternary Geology of Canada and Greenland. Geological Survey of Canada, Geology of Canada 1, 391-440.

Henderson, E.P., 1972. Surficial geology of Avalon Peninsula, Newfoundland. Geological Survey of Canada, Memoir 368.

House, R. and Catto, N.R., 1995. Sub-glacial underflow fan sedimentation, Avalon Peninsula, Newfoundland. CANQUA abstracts CA22, CANQUA/ CGRG 95, St. John's, Newfoundland.

Jenness, S.E., 1960. Late Pleistocene glaciation of eastern Newfoundland. Geological Society of America Bulletin, 71: 161-180.

Jukes, J.B., 1842. Excursions in and about Newfoundland during the years 1839 and 1840. John Murray, London.

1843. General report of the Geological Survey of Newfoundland, during the years 1839 and 1840. John Murray, London.

Kaszycki, C.A., 1987. A model for glacial and proglacial sedimentation in the Shield terrane of southern Ontario. Canadian Journal of Earth Sciences, 24: 2373-2391.

Kaufman, D.S., Miller, G.H., Stravers, J.A. and Andrews, J.T., 1993. Abrupt early Holocene (9.9 - $9.6 \mathrm{ka}$ ) ice-stream advance at the mouth of Hudson Strait, Arctic Canada. Geology, 21: 1063-1066.

Kerr, J.H., 1870. Observations on ice marks in Newfoundland. Geological Society of London, Quarterly Journal, 26: 704-705.

King, A.F., 1988. Geology of the Avalon Peninsula, Newfoundland. Newfoundland Department of Mines, Mineral Development Division, Map 88-01.

King, L.H. and Fader, G.B., 1986. Wisconsin glaciation of the Atlantic continental shelf of southeast Canada. Geological Survey of Canada, Bulletin 363.

1992. Quaternary geology of southern Northeast Newfoundland Shelf. Geological Association of Canada, Abstracts, A57, Wolfville.

Klassen, R.A. and Henderson, P.J., 1992. Quaternary geological studies, Buchans area of Central Newfoundland. Geological Survey of Canada, Paper 92-1D: 11-19.

Koteff, C., Robinson, G.P., Goldsmith, R. and Thompson, W.B., 1993. Delayed postglacial uplift and synglacial sea levels in coastal central New England. Quaternary Research, 40: 46-54.

Kulig, J.J., 1996. The glaciation of the Cypress Hills of Alberta and Saskatchewan and its regional implications. Quaternary International, 32: 53-77.

Lagerlund, E., Persson, K.M., Krzyszkowski, D., Johansson, P., Dobracka, E., Dobracki, R. and Panzig, W.-A., 1995. Unexpected ice flow directions during the Late Weichselian deglaciation of the South Baltic area indicated by a new lithostratigraphy in NW Poland and NE Germany. Quaternary International, 28: 127-144.

Levesque, A.J., Mayle, F.E., Walker, I.R. and Cwynar, L.C., 1993. The AmphiAtlantic Oscillation: A proposed Late-glacial climatic event. Quaternary Science Reviews, 12: 629-643.

Lewis, C.F.M., Macpherson, J.B. and Scott, D.B., 1987. Early sea leve transgression, eastern Newfoundland. INQUA 1987, Ottawa, Programme with Abstracts, 210.

Lindström, E., 1989. Are roches moutonnées mainly preglacial forms? Geografiska Annaler, 70A: 323-331.

Liverman, D.G.E., 1992. Application of regional Quaternary mapping to mineral exploration, northeast Newfoundland, Canada. Transactions of the Institution of Mining and Metallurgy, Section B, 110: B89-B98. 
1994. Relative sea-level history and isostatic rebound in Newfoundland, Canada. Boreas, 23: 217-230.

Lundqvist, J., 1969. Problems of the so-called Rogen moraine. Sveriges Geologiska Undersökning, Series C, 648, 32 p.

1989. Rogen (ribbed) moraine - identification and possible origin. Sedimentary Geology, 62: 281-292.

MacClintock, P. and Twenhofel, W.H., 1940. Wisconsin glaciation of Newfoundland. Geological Society of America Bulletin, 51: 1729-1756.

Macpherson, J.B., 1982. Postglacial vegetational history of the eastern Avalon Peninsula, Newfoundland, and Holocene climatic change along the eastern Canadian seaboard. Géographie physique et Quaternaire, 36: 175-196.

1995. A 6 ka reconstruction for the island of Newfoundland from a synthesis of Holocene lake-sediment pollen records. Géographie physique et Quaternaire, 49: 163-182.

1996. Delayed deglaciation by downwasting of the northeast Avalon Peninsula, Newfoundland: An application of the early Postglacial pollen record. Géographie physique et Quaternaire, 50: 201-220.

McCartney, W.D., 1967. Whitborne map-area, Newfoundland. Geological Survey of Canada, Memoir 341.

McConnell, R.G., 1885. Report on the Cypress Hills, Wood Mountain, and adjacent country. Geological Survey of Canada, Annual Report $1 \mathrm{C}$.

Miller, A.A.L. and Fader, G.B.J., 1995. A Late Pleistocene-early Holocene local independent ice cap on the Tail of the Grand Banks: Foraminiferal evidence. CANQUA abstracts CA 33, CANQUA/CGRG 95, St. John's, Newfoundland.

Milne, J., 1874. Notes on the physical features and mineralogy of Newfoundland. Geological Society of London, Quarterly Journal, 30: 722745.

1876. Ice and ice-work in Newfoundland. Geological Magazine, n.s., 3: 303-308; 345-350; 403-410.

1877. On the rocks of Newfoundland. Geological Magazine, n.s., 4: 251 262.

Mott, R.J. and Stea, R.R., 1995. The chronology of Late-glacial vegetation and climatic change in the Maritimes. CANQUA abstracts CA53, CANQUA/ CGRG 95, St. John's, Newfoundland.

Munro, M., 1994. The Quaternary history of the Carmanville (NTS 2E/8) area, northeast Newfoundland. M.Sc. thesis, Department of Geography, Memorial University, St. John's.

Munro, M. and Catto, N.R., in press. Quaternary geology of the Carmanville (NTS 2 E/8) area, Newfoundland. Geological Survey Branch, Ministry of Natural Resources, Government of Newfoundland and Labrador.

Murray, A., 1883. Glaciation of Newfoundland. Royal Society of Canada, Proceedings and Transactions, 1, sec. IV: 55-76.

Packard, A.S., 1876. Ice-marks in Newfoundland. American Naturalist, 10: 694-695.

Phillips, F.M., 1995. Cosmogenic Chlorine-36 Accumulation: A method for dating Quaternary Landforms. In N.W. Rutter and N.R. Catto, eds., Dating Methods for Quaternary Deposits. Geological Association of Canada, 6166.

Piper, D.J.W., Mudie, P.J., Fader, G.B., Josenhans, H.W., Maclean, B. and Vilks, G., 1990. Quaternary Geology. In M.J. Keen and G.L. Williams, eds., Geology of the Continental Margin of Eastern Canada. Geological Survey of Canada, 2: 475-607.

Prest, V.K., 1973. Surficial deposits, Prince Edward Island. Geological Survey of Canada, Map 1366 A.

Quinlan, G. and Beaumont, C., 1981. A comparison of observed and theoretical postglacial relative sea level in Atlantic Canada. Canadian Journal of Earth Sciences, 18: 1146-1163.

1982. The deglaciation of Atlantic Canada as reconstructed from the postglacial relative sea-level record. Canadian Journal of Earth Sciences, 19: 2232-2246.
Rogerson, R.J., 1981. The tectonic evolution and surface morphology of Newfoundland, p. 24-55. In A.G. Macpherson and J.B. Macpherson, eds., The Natural environment of Newfoundland past and present. Memorial University of Newfoundland, St. John's.

1982. The glaciation of Newfoundland and Labrador, p. 37-56. In P. Davenport, ed., Prospecting in areas of glaciated terrain. Canadian Institute of Mining and Metallurgy, Geology Division.

Rogerson, R.J. and Tucker, C.M., 1972. Observations on the glacial history of the Avalon Peninsula, Newfoundland. Maritime Sediments, 8: 25-31.

Rudberg, S., 1992. Multiple glaciation in Scandinavia - seen in gross morphology or not ? Geografiska Annaler, 72 A: 231-243.

Schau, M., 1981. Direction of Movement of glacially transported boulders not necessarily shown by preserved ice-movement direction indicators, Baker Lake, District of Keewatin. Geological Survey of Canada, Paper 81-1A: 383.

Seaman, A.A., Broster, B.E., Cwynar, L.C., Lamothe, M., Miller, R.F. and Thibault, J.J., 1991. Late Glacial and Post-Glacial Events in Coastal Environments, southwestern New Brunswick. CANQUA Field Trip Guidebook, Fredericton.

Shaw, J., 1979. Genesis of the Sveg tills and Rogen moraines of central Sweden: A model of basal melt-out. Boreas, 8: 409-426.

1983. Drumlin formation related to inverted melt-water erosional marks. Journal of Glaciology, 29: 461-479.

1994. A qualitative view of sub-ice-sheet landscape evolution. Progress in Physical Geography, 18: 159-184.

Shaw, J., Kvill, D. and Rains, B., 1989. Drumlins and catastrophic subglacial floods. Sedimentary Geology, 62: 177-202.

Shaw, J. and Forbes, D.L., 1995. The postglacial relative sea-level lowstand in Newfoundland. Canadian Journal of Earth Sciences, 32: 1308-1330.

Slatt, R.M., 1972. Texture and composition of till derived from parent rocks of contrasting textures: Southeastern Newfoundland. Sedimentary Geology, 7: 283-290.

Stea, R.R., 1995. Late Quaternary glaciation and sea-level change along the Atlantic Coast of Nova Scotia: Correlation of Land and Sea events. CANQUA abstrasts, CA 47, CANQUA/CGRG 95, St. John's.

Stea, R.R., Forbes, D.L. and Mott, R.J., 1992. Quaternary geology and coastal evolution of Nova Scotia. Geological Association of Canada, Guidebook, Field Excursion A-6, Wolfville.

Stea, R.R. and Mott, R.J., 1993. Late-glacial (Allerød-Younger Dryas) buried organic deposits, Nova Scotia, Canada. Quaternary Science Reviews, 12: 645-657.

Stehman, C.F., 1976. Pleistocene and Recent sediments of northern Placentia Bay, Newfoundland. Canadian Journal of Earth Sciences, 13: 1386-1392.

Sugden, D.E., Glasser, N. and Clapperton, C.M., 1992. Evolution of large roches moutonnées. Geografiska Annaler, 74 A: 253-264.

Sulerzhitsky, L.D., 1997. Peculiarities of Radiocarbon Chronology of Younger Dryas Deposits in the Taimyr Peninsula. Quaternary International, 41/42: 119-124.

Summers, W., 1949. Physical geography of the Avalon Peninsula of Newfoundland. M.Sc. thesis, McGill University, Montreal.

Tanner, V., 1944. Outline of the geography, life, and customs of Newfoundland and Labrador. Acta Geografiska, 8: 1-907, Helsinki.

Taylor, D.M., St. Croix, L. and Vatcher, S.V., 1994. Newfoundland Striation Database. Newfoundland Department of Mines and Energy, Geological Survey Branch, Open File 2195.

Twenhofel, W.H. and MacClintock, P.A., 1940. Surface of Newfoundland. Geological Society of America Bulletin, 51: 1665-1728.

Vanderveer, D.G., 1975. The surficial geology of the St. John's area, Newfoundland, with special emphasis on gravel resources. Newfoundland and Labrador Department of Mines and Energy, Geological Survey Branch, Open File 1 N/232. 
1977. Surficial and Glacial Geology, Gravel Resource Inventory, Isthmus of Avalon area. Mineral Development Division, Department of Mines and Energy, Government of Newfoundland and Labrador, Open File 960.

Velichko, A.A., Kononov, Y. M. and Faustova, M.A., 1997. The Last glaciation of the Earth: The Size and Volume of Ice Sheets. Quaternary International, 41/42: 43-52.

Vincent, J.-S., 1989. Quaternary Geology of the Southeastern Canadian Shield, p. 249-275. In R.J. Fulton, ed., Quaternary Geology of Canada and Greenland. Geological Survey of Canada, Geology of Canada 1.
Wellner, R.W., Ashley, G.M. and Sheridan, R.E., 1993. Seismic stratigraphic evidence for a submerged middle Wisconsin barrier: Implications for sealevel history. Geology, 21: 109-112.

Willey, J.D., 1976. Geochemistry and environmental implications of the surficial sediments in northern Placentia Bay, Newfoundland. Canadian Journal of Earth Sciences, 13: 1393-1410.

Wolfe, A.P. and Butler, D.L., 1994. Late-glacial and early Holocene environments at Pine Hill Pond, Newfoundland, Canada: Evidence from pollen and diatoms. Boreas, 23: 53-65. 